Florida International University

FIU Digital Commons

FIU Electronic Theses and Dissertations

University Graduate School

$5-14-1998$

\title{
Occupational therapy in Iceland attitude, knowledge and cooperation
}

Gunnhildur Gisladottir

Florida International University

Follow this and additional works at: https://digitalcommons.fiu.edu/etd

Part of the Occupational Therapy Commons

\section{Recommended Citation}

Gisladottir, Gunnhildur, "Occupational therapy in Iceland attitude, knowledge and cooperation" (1998). FIU Electronic Theses and Dissertations. 3942.

https://digitalcommons.fiu.edu/etd/3942

This work is brought to you for free and open access by the University Graduate School at FIU Digital Commons. It has been accepted for inclusion in FIU Electronic Theses and Dissertations by an authorized administrator of FIU Digital Commons. For more information, please contact dcc@fiu.edu. 
FLORIDA INTERNATIONAL UNIVERSITY

Miami, Florida

OCCUPATIONAL THERAPY IN ICELAND

ATTITUDE, KNOWLEDGE AND COOPERATION

A thesis submitted in partial satisfaction of the

requirements for the degree of

MASTER OF SCIENCE

IN

OCCUPATIONAL THERAPY

by

Gunnhildur Gisladottir 
To: Dean DeLois Weekes

College of Health Sciences

This thesis, written by Gunnhildur Gisladottir, and entitled Occupational Therapy in Iceland: Attitude, Knowledge and Cooperation, having been approved in respect to style and intellectual content, is referred to you for judgement.

We have read this thesis and recommend that it be approved.

\author{
Susan Kaplan
}

Paulette Johnson

James L. Mills, Major professor

Date of Defense: May 14, 1998

The thesis of Gunnhildur Gisladottir is approved.

Dean DeLois Weekes

College of Health Sciences

Dr. Richard L. Campbell

Dean of Graduate Studies

Florida International University, 1998 
"Only those who will risk going too far can possibly find out how far one can go."

T.S. Elliot 


\author{
ABSTRACT OF THE THESIS \\ OCCUPATIONAL THERAPY IN ICELAND: \\ ATTITUDE KNOWLEDGE AND COOPERATION \\ by \\ Gunnhildur Gisladottir \\ Florida International University, 1998 \\ Miami, Florida \\ Professor James L. Mills, Major Professor
}

The purpose of this study was to discover attitudes and knowledge of four health care student groups toward occupational therapy in Iceland.

A fact-sheet identifying philosophy, theoretical background, skills roles and occupational therapy working areas was developed. Pre-test and post-test questionnaires were used to measure any attitude and knowledge changes which might have occurred after reading the fact-sheet.

The results demonstrated that the four student groups had obtained knowledge about occupational therapy during their university experiences; either from in class information or from field trips to occupational therapy departments. The questionnaire results indicated that students' attitudes toward cooperation with occupational therapists was positive. The overall outcome indicated that as a result of information gained from the fact-sheet, significant attitude and knowledge changes were demonstrated among the four student groups about occupational therapy in Iceland. 
CHAPTER I 1

Introduction 1

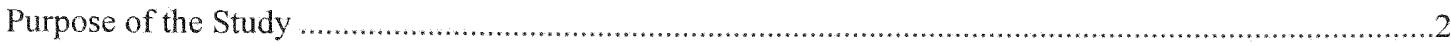

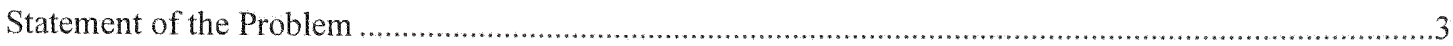

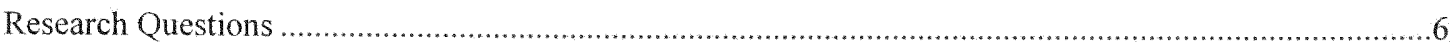

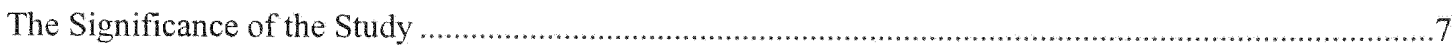

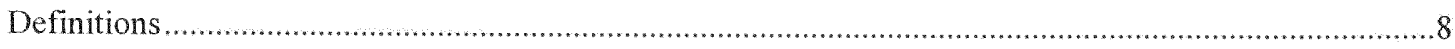

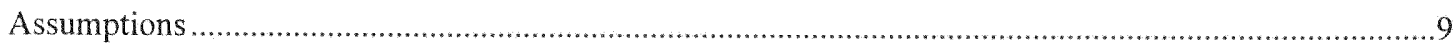

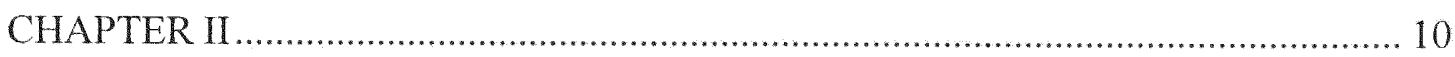

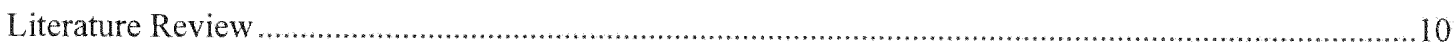

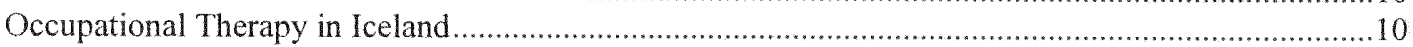

Health Professional Education in the University of Iceland .........................................................11

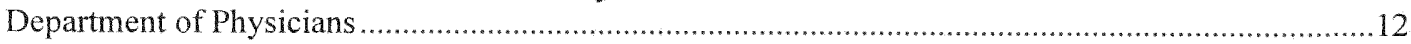

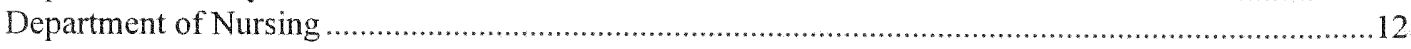

Department of Physical Therapy ........................................................................................... 14

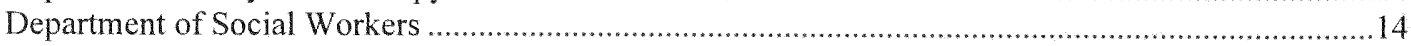

Attitudes Toward Occupational Therapy ….................................................................................. 15

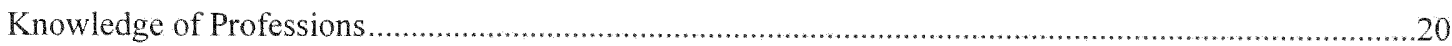

Cooperation Between Health Care Professionals ............................................................................223

The Client's Benefits of Increased Knowledge between Health Care Professions ..................................25

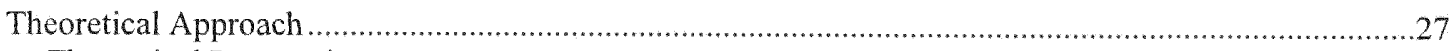

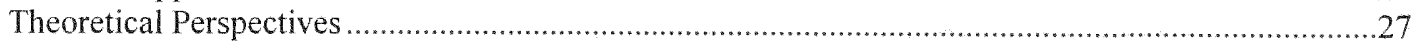

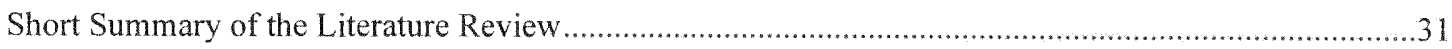

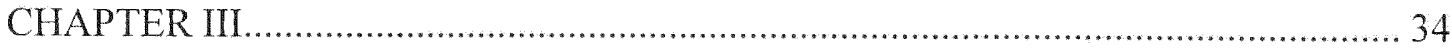

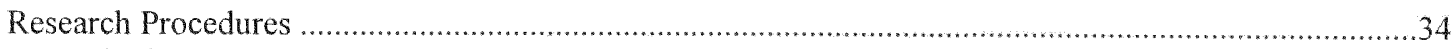

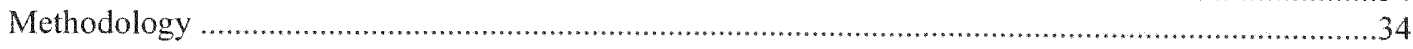

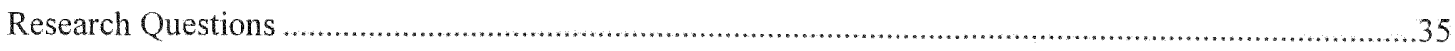




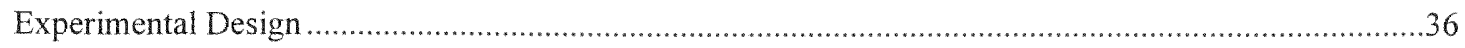

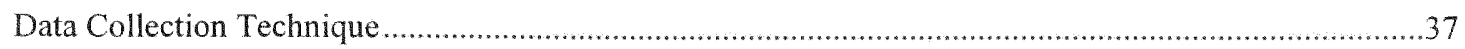

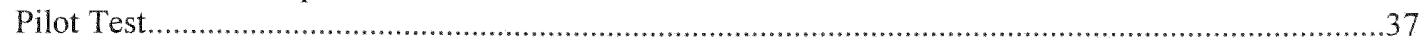

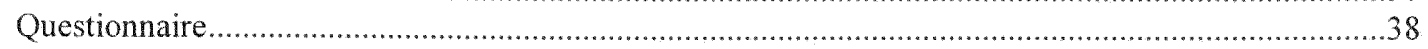

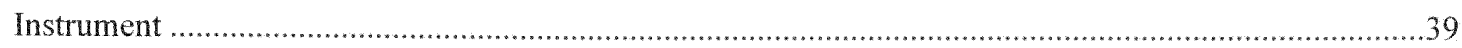

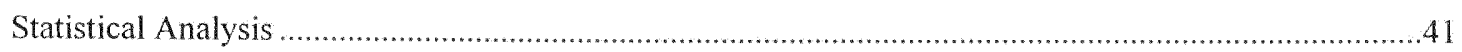

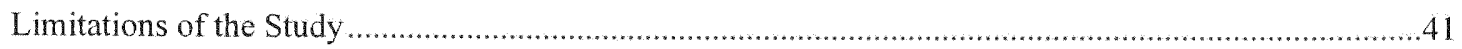

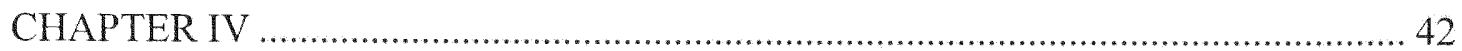

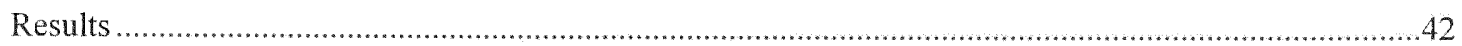

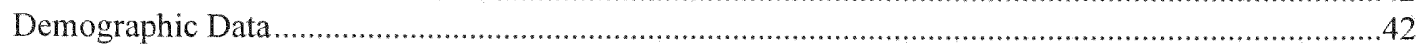

Section A - Your background and acquaintance with occupational therapy ...............................42

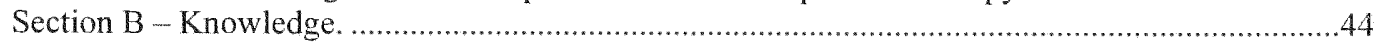

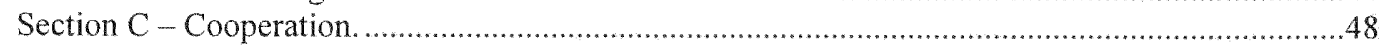

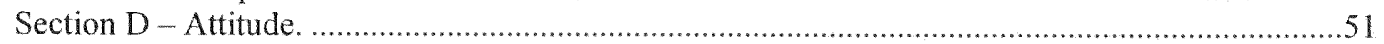

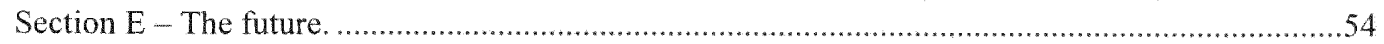

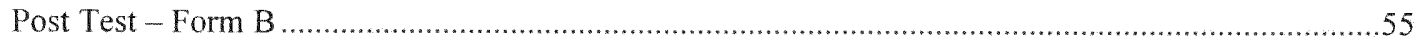

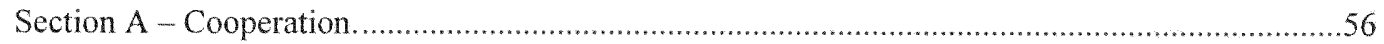

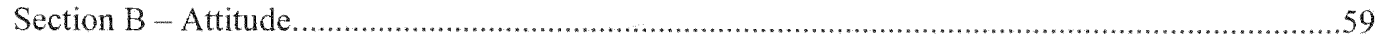

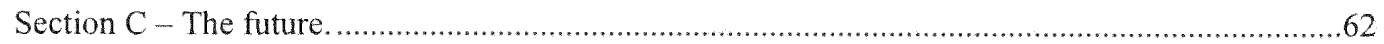

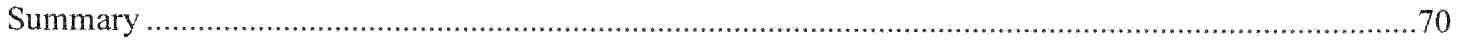

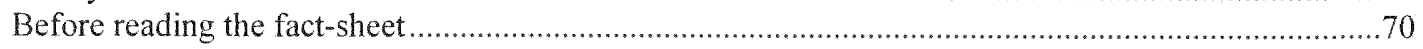

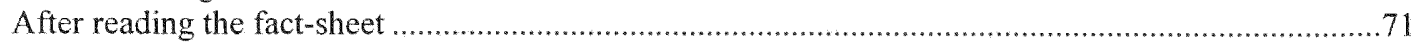

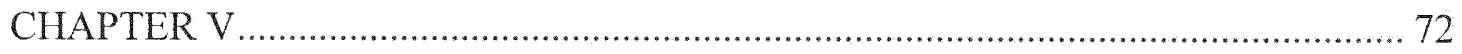

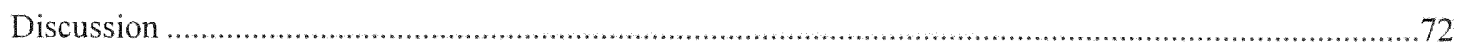

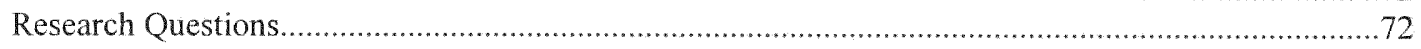

The Changes that Occurred Among the Four Student Groups Regarding

Knowledge and Attitudes After Reading the Fact-sheet .............................................................72

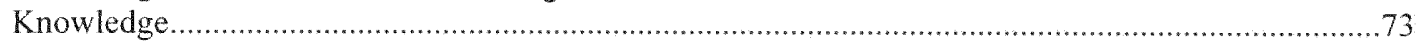

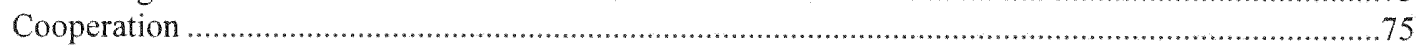

The Attitudes of the Four Student Groups Towards Occupational Therapy in Iceland...........................77

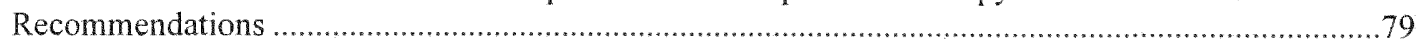

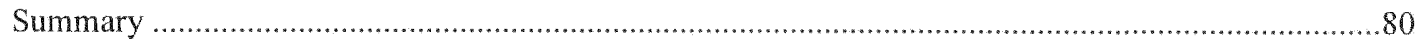

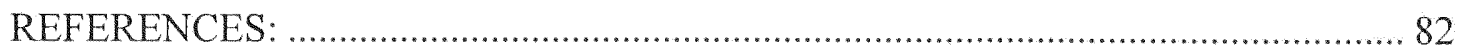

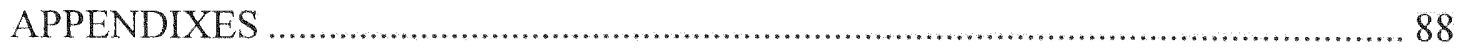




\section{List of Tables}

Table 1 Frequencies and Percentages on Knowledge Questions Answered by Four Health Care Student Groups Regarding Occupational Therapy.

Table 2 Analysis of Variance on Agreement on Cooperation Questions Answered by Four Health Care Student Groups Regarding Occupational Therapy.....

Table 3 Analysis of Variance on Agreement on Attitude Questions Answered by Four Health Care Student Groups Regarding Occupational Therapy

Table 4 Analysis of Variance on Agreement on Future Questions Answered by Four Health Care Student Groups Regarding Occupational Therapy....

Table 5 Analyses of Variance on Differences in Agreement on Cooperation Questions from Form A to Form B by Health Care Student Groups and $t$ Tests on Differences for the Whole Sample ......57

Table 6 Analyses of Variance on Difference in Agreement on Attitude Questions from Form A to Form B by Health Care Student Groups and $t$ Tests on Differences for the Whole Sample

Table 7 Analyses of Variance on Difference in Agreement on Future Questions from Form A to Form B by Health Care Student Groups and $t$ Tests on Differences for the Whole Sample ......63

Table $8 \quad t$ Tests of Differences Between Form A and Form B for Each Student Group ..... .66

Table 9 Analysis of Variance on the Statement Regarding Changes of the Students' Ideas about Occupational Therapy, by Four Health Care Student Groups

Table 10 Analysis of Variance on the Statement Regarding Whether or not There were Facts on the Fact-sheet That the Students Knew Before, by Four Health Care Student Groups .69 


\section{List of Figures}

Figure 1-Distribution of the results from the statement regarding changes of the students ideas about occupational therapy

Figure 2 -Distribution of the results from the statement regarding whether or not there were facts on the fact-sheet that the students knew before. 


\section{Chapter I}

\section{$\underline{\text { Introduction }}$}

Throughout the history of occupational therapy the discipline has sought to maintain a balance of cooperation and autonomy in its relationship with the other health professions (Coleman, 1992). Currently, quality health care requires a skilled and knowledgeable workforce. Collaboration, effective communication and teamwork are required in order to provide quality service to clients. Each profession, including its beliefs, knowledge and skills, is unique because members of that profession have mastered certain skills (Mosey, 1985). Therefore, it is vitally important that professionals understand and respect the knowledge and skills that each individual profession contributes to the treatment process (Richard, 1994 ; Gage, 1995).

Occupational therapy is a fairly young profession in Iceland and not well known. Most health care professions in Iceland are not familiar with the role of occupational therapists and how to cooperate with them. This lack of knowledge by other health care professions regarding occupational therapy can cause difficulties in coordinating the services of many independent specialists and in meeting the needs of the client (Palmadottir, 1996 ; Gage, 1995).

Education of the health care profession students is the fundamental building block of professional socialization in that it conveys the basic knowledge, skills, theories and attitudes that are the essence of each profession. The students become professional by learning the content, acquiring the skills, and internalizing the values of their own profession along with other professions (Hayden, 1995). 
Physicians, nurses, physical therapists and social workers in Iceland are almost all educated at the University of Iceland and these studies are all completed with a Bachelor degree. In the future, occupational therapists will also be educated in the same University. Occupational Therapy started as an academic program in the University of Iceland in the autumn of 1997.

If students in the health care professions had more opportunities to work together, gain information about each other's specialties and develop relationships with other health care professions, would interdisciplinary cooperation improve? Would the service to the clients be more effective and successful if greater trust between health care professions was established? To be able to find answers to these questions it is important to know how much the professions know about each other. As I am an occupational therapist, my interests are to find out what knowledge medical, nursing, physical therapy and social work students have about occupational therapy in Iceland and what the attitudes exist among Icelandic medical, nursing, physical therapy and social work students toward occupational therapy.

\section{Purpose of the Study}

The purpose of this study is to discover the attitudes and knowledge of four groups of health care professional students toward occupational therapy in Iceland. The students are all in their last year in medical, nursing, physical therapy, and social work programs at the University of Iceland. 


\section{Statement of the Problem}

Members of an interdisciplinary treatment team can not function competently and effectively if team members do not have an understanding of their own identity and a working knowledge of each other's specialties. This applies to all professions including occupational therapists, physicians, nurses, physical therapists, and social workers. Professionals need to practice cooperatively without interfering in the role and duties of another discipline. As a team each discipline contributes their unique perspective in the treatment of the client (Yerxa, 1995; Gage, 1995).

In Allen and Cruckshank's research from 1977, one hundred randomly selected occupational therapists stated that the most bothersome problem of all in their profession was "Getting other professionals to understand and respect the role of occupational therapy" (Allen and Cruckshank, 1977, p. 562). The authors gave three possible explanations for this problem:

1) that occupational therapists are not successful in explaining their diverse and dissimilar functions to other professionals;

2) that occupational therapists are insecure because of a lack of technical knowledge and therapeutic skills and are not assertive enough in their explanations of their roles; and

3) that occupational therapists frequently lack knowledge in evaluating systems and they have difficulty in working effectively within alien systems (Allen and Cruckshank, 1977).

Parham (1987) wrote that it was no wonder that society had not granted occupational therapists the prestige and autonomy accorded to well-established 
professions. The occupational therapy profession had not demonstrated that it would and could give back to society a sound body of knowledge, carefully evaluated services, or a substantial contribution to solving the health care problems of the nation. She also declared that professional thinking involves being able to analyze reasons for decisions, actions, and the ability to articulate the theories behind occupational therapy practice. This would convince other professionals that occupational therapists are striving for a higher level of professionalism (Parham, 1987).

Yerxa (1995) indicated that the occupational therapists needed to develop national coalitions with other professions to influence public policy, to develop supportive and strengthening alliances with other academic disciplines in the university. She also wrote that occupational therapists needed to strengthen their position as an academic discipline, contributing to the universe of knowledge as an occupational therapy academic department (Yerxa, 1995). Gilfoyle stated that educational programs in occupational therapy are under increasing pressure to expand and clarify their roles within universities. Occupational therapists should engage in scholarly endeavors such as research and program development to generate new knowledge and advance the science of occupational therapy to solidify their rightful place in universities (Gilfoyle, 1988 ; Lane, 1990).

If the health care profession students became aware of each other's resources and knowledge in their study-time they could improve cooperation in their professional working areas. This could be done by developing relationships with other professional students by discussing their roles, ideas, cases, program development and clinical problems. The students could ask questions about each other's theories and research and 
offer insights from each special field. Collaborating between students from different professions in health care on clinical projects, presentations, or research can be an effective avenue for demonstrating the value of each profession. It could be a great learning process asking other health care profession students about their thoughts, similarities and differences on a problem, and analyzing the different points of view (Parham, 1987). The process of this introduction to other professional areas could begin with small, intramural projects and lead to the development of more qualified people who can cooperate. This approach enables occupational therapy as well as other health care professions to gain a foothold within the universities as well as building the knowledge of occupational therapy itself (Dunn and Boyle, 1994).

In Iceland there is tendency to look at occupational therapy as a technical education rather than a professional one. Therefore, it is necessary that occupational therapy education is at the same level as the education of those health professionals to whom occupational therapists usually compare themselves (Palmadottir, 1996).

If the health care professional students had more opportunities to work together, gain information about each other's specialties and to develop relationships with other health care professions, would their cooperation improve? One way to make the work with the clients more effective and successful could be to establish trust toward other health care professions.

In almost every hospital, rehabilitation center and other health care institution in Iceland, there is cooperation between the health care professionals, including physicians, nurses, physical therapists, social workers and occupational therapists. However, at the University of Iceland these different health care students have very few opportunities to 
be come acquainted with one another. In the curriculum of the four health care professions there are not opportunities for the students to become informed about the other health care professions and the necessity for interdisciplinary cooperation. Because of the geographic location of the departments in the University of Iceland these departments are separated so the students have limited opportunities to meet; therefore, the students in the different health care professions interact for the first time in their field placements.

In Iceland, the doctor refers the patient to occupational therapy; and therefore, it is essential that the roles and function of occupational therapists be clearly understood by the physicians. In referring occupational therapy to the client, the doctor is entrusting the occupational therapist with the opportunity to contribute to the present and future welfare of an individual. The doctor is relying on the occupational therapist's judgment and skills to be applied with scientific knowledge and sincerity for the client's benefit (Scullin, 1943).

\section{Research Questions}

I will survey the knowledge and attitudes of four Icelandic health care professional student groups regarding occupational therapy in Iceland.

1. What do medical, nursing, physical therapy and social work students know about occupational therapy in Iceland?

2. What attitudes do Icelandic medical, nursing, physical therapy and social work students have toward occupational therapy? 
3. What changes occurred among the students in the four groups of health care professions regarding knowledge and attitude after reading a fact-sheet?

\section{The Significance of the Study}

The significance of the study was to describe the attitudes and knowledge of four groups of Icelandic health care professional students concerning occupational therapy in Iceland. The four groups of students were all in their last year of medical, nursing, physical therapy and social work at the University of Iceland.

It was assumed that these beliefs will influence how the students will work with occupational therapists when they finish their study and start working in hospital or other health care settings.

It is expected that the health care students who show supportive attitudes and knowledge regarding occupational therapy will be more prone to work with the occupational therapists after beginning work in the health care field. The cooperation would be better between the health care professions and qualified to give the clients a proper treatment.

This study is important since the survey measures the knowledge and attitude of the four academic students regarding occupational therapy in Iceland. Not only are the results interesting for the occupational therapy profession in Iceland, but also to the other four health care professions, and hopefully the first step to better communication and cooperation between students of different academic professions. Furthermore the result should be helpful in convincing the University of Iceland to approve the curriculum and support orientation between different health care profession students. 


\section{Definitions}

Occupational Therapy: ...is a health profession whose members collaborate in enabling occupation with clients, who may be individuals, groups, or organizations. The emphasis has been on individuals whose lives have been disrupted by illness, disability, addictions, the effects of aging, or social disadvantages (Canadian Association of Occupational Therapists, 1997).

Occupational therapy aims to help disabled people to maximize their potential capabilities so that they may achieve their highest level of function and independence in all aspects of daily life (Chakravorty, 1993).

Knowledge: "Acquaintance with or understanding of..." (Merriam Webster, 1994, p.647).

Attitude: $\quad$ "...is a state of readiness, a tendency to act or react in a certain manner when confronted with certain stimuli. Thus, the individuals' attitudes are present but dormant most of the time, they become expressed in speech or other behavior only when the object of the attitude is perceived" (Oppenheim, 1966, p.105-106).

..."predisposition to respond in a particular way toward a specified class of objects" (Rosenberg and Hovland, 1960, p.1). "Attitudes are reinforced by beliefs (the cognitive component) and often attract strong feelings (the emotional component) that will lead to 
particular forms of behavior (the action tendency component)" (Oppenheim, 1966, p.105-106).

Profession: "...a homogenous community of members who share identity, values, and definitions of roles and interests" (Bucher and Strauss, 1961, p.325). "...Profession establishes and sustains its own practice, education, and standards on the basis of its unique body of knowledge" (Blane, 1991, p.2).

Body of knowledge: "A profession is made up of theories that are:

1. selected from a variety of sources because they have specific relevance to practice, and

2. are developed by the profession" (Mosey, 1985, p.505).

Professional practice: "... is what the profession does: the purposeful application of knowledge, skills and techniques to achieve redefine goals, utilizing compatible frameworks and models that do not compromise the shared value system" (Creek and Ormston, 1996, p.7).

\section{Assumptions}

In conducting this study the following assumptions were made:

1. Students will be truthful and honest in completing the questionnaires.

2. Study subjects have limited knowledge of occupational therapy.

3. Study subjects have had limited contact with occupational therapy. 


\section{Chapter II}

\section{Literature Review}

\section{Occupational Therapy in Iceland}

Developed in 1977, occupational therapy in Iceland is a young profession. Since 1977, the number of practicing occupational therapists has increased from eight to 84 (Dec. 1997). The population of Iceland is only 265,000 , which means that there are about 25 occupational therapists per 100,000 people (Palmadottir, 1996 ; Palmadottir, 1997).

In the autumn of 1997 , an occupational therapy department was started at the University of Iceland. So far, no occupational therapists have graduated from that department. Current Icelandic occupational therapists were all educated abroad. The cost of education abroad and the difficulties involved with moving to a foreign country, learning a new language and adapting to a new culture are hindrances for many young people. This means that there is a very low rate of increase in practicing occupational therapists. Three to four occupational therapists graduate each year and return to Iceland. Most Icelandic occupational therapists are educated in Scandinavian countries: Denmark, Sweden and Norway. A few have had their training in Western Europe and in North America. The differences in education means that the education does not always meet the specific needs of the Icelandic health care system and Icelandic occupational therapists miss a common base from which to define their role and professional identity (Palmadottir, 1996). 
Occupational therapy services in Iceland started within general hospitals and rehabilitation centers and 65 out of 84 occupational therapists in Iceland still practice within such institutions. Half of the Icelandic population lives in the capital area. Of the 84 practicing occupational therapists, 75 work in that geographical area, leaving only nine for the rest of the country. About half of the occupational therapists work in the physical dysfunction area, but there is lack of occupational therapists working in the mental health area. No occupational therapists practice within the state school system, in institutions for the elderly or in the community providing home care services. Occupational therapy services people with daily life problems. Those who need occupational therapy must be referred to a hospital or a rehabilitation center (Palmadottir, 1996 ; Palmadottir, 1997).

\section{Health Professional Education in the University of Iceland}

The University of Iceland was established in 1911 and is located in Reykjavik, the capital of Iceland. Today the University of Iceland serves a nation of approximately 265,000 people and provides places for 5,900 students (57\% are female) studying in nine facilities. The University of Iceland offers opportunities for study and research in the humanities, natural sciences and social sciences, and in professional fields such as theology, law, business, medicine, dentistry and engineering (Gudmundsson, et. al,, 1994). 


\section{Department of Physicians}

The first physicians' program in Iceland was established in 1876. The University of Iceland was established in 1911 and a medical department was a part of the curriculum from the start (Gudmundsson, et. al., 1994).

Every person who has finished high school can be admitted the first semester and, in recent years, approximately 150 individuals have required admission annually. Only 30 students of the 150 can continue their studies into the spring term. Autumn grades determine who can continue. The students who successfully complete the study receive the candidate medical and chirurgeon (surgeon) degree (Gudmundsson, et. al., 1994).

The physician's curriculum aims to provide a solid background for further specialization in medicine. The students have to go abroad to gain the specialization (Gudmundsson, et. al., 1994).

The physician's curriculum lacks courses which provide interdisciplinary cooperation with other health team members; furthermore, there is only one course which requires interaction with the client (Gudmundsson, et. al., 1994).

\section{Department of Nursing}

The first Icelandic nurses joined the evolving practices of nursing in Iceland at the beginning of this century. Icelandic nurses went abroad for their training until the Icelandic School of Nursing was established in 1931. A Department of Nursing was established in 1973 in the University of Iceland (Gudmundsson, et. al., 1994). 
From 1973 - 1986, two nursing education programs were operating in Iceland. The Nursing School of Iceland was, by legislation, closed in the spring of 1986. A baccalaureate degree became the sole entry into nursing practice in Iceland. In 1992 a special program for Registered Nurses with diploma education to obtain a Bachelor of Science degree in nursing was established at the University of Iceland (Ingadottir, 1996).

The Department of Nursing is closely associated with the School of Medicine and works with many of their faculty members, yet it has full autonomy to function within the university structure (Ingadottir, 1996).

Acceptance into the curriculum is completion of high school. Only 60 students are allowed to continue their studies in the spring term based on their grades in the autumn term exams. A student who successfully completes the baccalaureate program receives the Bachelor of Science degree in Nursing (Gudmundsson, et. al., 1994).

The foundation of nursing is based on the knowledge and understanding of man. The science of nursing deals with the concepts, ideas, theories, and facts that give nurses the knowledge and understanding necessary to evaluate, maintain, and increase the health of the client. The need for nursing has developed from physical, emotional, and social needs of man. This is especially significant in the wake of illnesses, health problems, and changes in development. Nursing is then directed to promoting the strengths of the person, the family and/or the society, and to encouraging independence, well being, and health. In the nursing curriculum, one of the goals (number seven of eight) is that nursing aims to "take active part in teamwork with health professionals and others who are in health-related work" (Ingadottir, 1996, p.3). 


\section{Department of Physical Therapy}

The Physical Therapy Department in the University of Iceland was established in 1976. Before that time, the students had to go abroad to gain this education. The study is four years in length and is completed with a Bachelor of Science degree (Gudmundsson, et. al., 1994).

To be accepted into the curriculum, the student has to have finished high school. In recent years, about 80 people have been admitted; twenty students can continue to the spring term. Continued study is based on their grades on the autumn term exams (numerus clausus). In the physical therapy curriculum, there are no courses available in cooperation with other health team members (Gudmundsson, et. al., 1994).

\section{Department of Social Workers}

The Department of Social Workers at the University of Iceland was established in 1976. The study takes at least four years and the students have to have finished high school before being admitted to the program. All applicants who meet the admission requirements are admitted to the first two semesters, but in the third and fourth terms only; 15 students can continue based on grades on their exams (numerus clausus) (Adalsteinsdottir, 1996).

In the social work curriculum, there are no courses available in cooperation with other health team members (Gudmundsson, et. al., 1994). 


\section{Attitudes Toward Occupational Therapy}

Parham (1987) wrote that it's no wonder that society has not granted occupational therapists the prestige and autonomy accorded the well-established professions. According to Parham, the occupational therapy profession has not demonstrated that it could and would give back to society a sound body of knowledge, carefully evaluated services, and substantive contributions to help solve health care problems of the nation (Parham, 1987).

Very few studies have been conducted to determine the level of awareness among health care professionals on knowledge of other health care professions. Only one survey has been done in the United Kingdom on awareness of a medical service among the hospital and community doctors of how they view occupational therapy. There has been little research on how other professions view occupational therapy. Despite the lack of research, the studies so far suggest that awareness of occupational therapy is limited and there are misconceptions about the profession. Moreover, in the changing and developing Nation Health Service, the improvement and maintenance of occupational therapy's status requires other professions to have a better understanding of occupational therapy. A first step to this understanding is to investigate the current attitudes of other professions about occupational therapy (Chakravorty, 1992, Kaur, et. al., 1996).

Kaur, Seager and Orrell (1996) focused their study on attitudes toward and knowledge about occupational therapy among mental health staff. Questionnaires were sent to staff working in a district general hospital psychiatric unit. The five groups of staff included psychiatrists, psychologists, social workers, qualified nurses and nursing 
assistants. In all, 64 out of 89 staff responded, giving an overall response rate of $72 \%, 18$ out of 21 psychiatrists, 4 out of 5 psychologists, 8 out of 8 social workers, 20 out of 26 nurses and 14 out of 29 nursing assistants (Kaur, et. al., 1996).

In the study, the most important role of the occupational therapist was thought to be to promote independence and coping abilities by $55(86 \%)$ respondents. The next most important role (38 staff, 59\%) appeared to be building confidence and social skills. Sixteen staff (25\%) thought those teaching specific skills, such as cooking and art, were most important roles of the occupational therapist. Ten (16\%) thought that preventing or distracting patients from dwelling on their problems was the most important role; $3(5 \%)$ said that reducing psychiatric symptoms and $2(3 \%)$ said that relieving boredom or loneliness were the most important roles for the occupational therapist (Kaur, et. al., 1996).

Only $14(22 \%)$ in this survey thought that there was no overlap between occupational therapists and other professions. In general, psychiatric, social workers and psychologists saw occupational therapy as having a large degree of overlap with the other professions; whereas, nurses saw the main overlap being with their own work. The authors of the survey discussed if this was because of blurring of roles or lack of understanding about the functions of occupational therapy. Overall, 52 (81\%) respondents thought that nurses were the professionals who should have the most communication with occupational therapists. Individually, each discipline emphasized that it ought to have a great deal of direct communication with occupational therapists as part of its work (Kaur, et. al., 1996). 
Interestingly, only $13(20 \%)$ respondents said that they were very confident that they understood the service provided by occupational therapy. This pattern was consistent across groups with only four (22\%) psychiatrists, five (25\%) nurses, two (25\%) social workers, no psychologists and two (14\%) nursing assistants being very confident that they understood the occupational therapy service. According to the authors of the survey, this indicates a general lack of understanding about occupational therapy and suggests that misconceptions could arise (Kaur, et. al., 1996).

In the survey, the authors discussed how the results of the survey can reflect the confusion about what occupational therapy is and/or the realities of clinical practice. The results of the study suggest that there needs to be an heightened awareness about the role of occupational therapy in the mental health unit amongst other disciplines and gave suggestions on how that could be done (Kaur, et. al., 1996).

Between 1990-1991, Chakravorty (1993) carried out a questionnaire study that examined the "awareness" of hospital consultants and general practitioners of the occupational therapy services provided by the District Health Authority occupational therapy service. The survey also compared the levels of awareness between these two groups.

The correct answer with respect to the duties of occupational therapists was expected to be assessment and rehabilitation of physically disabled people, people with learning disabilities, elderly people and mentally ill people to maximize independence in their daily living, and provide aids and necessary adaptations for them where appropriate (Chakravorty, 1993). 
Of the 28 hospital consultants, $18(64.8 \%)$ responded; from the group of 31 general practitioners, $21(67.7 \%)$ questionnaires were returned. Analysis of the replies suggested that awareness was better among the general practitioners than among the hospital consultants; six (33\%) of the 18 hospital consultants and $11(52 \%)$ of the 21 general practitioners knew the function of the occupational therapy service. However, the results of this survey indicate that awareness of occupational therapy as a specialty is in need of improvement. The hospital consultants, especially those who knew the service well, were in specialties of general medicine, geriatrics, psychiatric medicine, pediatrics and orthopedics. One of the psychiatric consultants, although referring patients for occupational therapy, did admit that he did not know enough about the service (Chakravorty, 1993).

In comparing referral rates between the two groups of doctors having better knowledge and limited knowledge, it was observed that there was a direct relationship between the referral rate and the awareness of the referring doctor (Chakravorty, 1993). The author stated that certain consultants might not need to use this service at all. This generally does not apply to general practitioners, but $10(47.6 \%)$ of the 21 general practitioners had never used this service for any of their patients (Chakravorty, 1993).

This study found that general practitioners appeared to be better informed about occupational therapy than were the hospital consultants. This is in contradiction to what was expected. Surprisingly, some of the consultants who had referred cases for occupational therapy knew little of the function of the service (Chakravorty, 1993). This study did show that awareness of this service was still lacking for about $50 \%$ of the general practitioners and 70\% of the hospital consultants (Chakravorty, 1993). 
In 1992-1993 Harries and Caan did a study where understanding of occupational therapy was examined by patients and staff in a 212-bed psychiatric hospital. Nineteen staff members were included in the study (16 nurses, two registrars and one senior registrar) because the role of occupational therapy in patient care has been misunderstood as "only to occupy his time and mind" or "to overcome boredom." Also, because most doctors and patients expect occupational therapy to be "time filling or diversional" (Harries and Caan, 1994, p.221).

One of the results of the study was that ward staff were most likely to differ from occupational therapists on the main purposes of therapy. Moreover, the ward staff agreed with the patients on that the role of occupational therapy was "to entertain you" (Harries and Caan, 1994).

Parker and Chan (1986) did a study to determine how occupational therapy and physical therapists perceive each other and other allied health professionals in terms of prestige. The participants were 56 occupational therapists and 48 physical therapists. They were asked to give each occupation a value that best gave their own opinion of the social standing that each occupation has. It was interesting that both physical therapists and occupational therapists rated physical therapists higher than occupational therapists. Occupational therapists had prestige scores of 77 (self rating) and 72 (physical therapists' rating). Physical therapists scored 82 (self rating) and 85 (occupational therapists' rating) (Parker and Chan, 1986).

One of the factors that occupational therapists have to consider is that the relationship that one establishes with other members of the health team will influence the reputation of the occupational therapist. The objective is to influence health 
professionals positively by presenting accurate, timely and relevant information on a regular basis (Krupnick, 1985).

\section{Knowledge of Professions}

Quality health care requires a knowledgeable and skilled work force. The levels of knowledge and skills have changed over the years so professions evolve to take advantage of new knowledge, new ideas and beliefs, and to meet society's ever-changing needs. Collaboration, effective communication and teamwork are all skills that every health professional needs in order to be able to perform qualified work with their clients (Mosey, 1985 ; Richard, 1994).

One of the major problems of competition among professions is related to overlapping areas of knowledge and expertise, similar professional status, and desires for advancement. The current economic climate in health care, which emphasizes reduced costs and increased productivity, contributes to the environment of increased competition, drives movement into new practice arenas, and demands evidence of expertise (Grady, 1987).

In the year 1995, Gage wrote that cross-training, new management models and the training of multi-skilled health care workers resulted in occupational therapists being dispersed between programs, or work groups, rather than consolidated in a department. According to the author, there is fear that without the unifying structure of a department, the system will cease to recognize the unique value of occupational therapy and that occupational therapy functions will be assumed by multi-skilled caregivers (Gage, 1995). 
That is not the future image that occupational therapists have of their profession. As Mosey wrote:

"The collective content of each profession is unique in its totality, not in its parts. In illustration, we share part of our body knowledge with other professions, such as human growth and development; we also share some of our philosophical assumptions, such as belief in the holistic nature of the individual. The content of a given profession, its beliefs, knowledge, and skills, is unique only because members of that profession have mastered it in its totality. Members of other professions and the average person may understand parts, but not the whole" (Mosey, 1985, p.508).

By being open minded, showing interest and concern, and asking questions, each profession is able to gain considerable information about the role of other professions. Prior concepts about what a department does may be misleading, and therefore, it is important to gain information from department members about their perception of role and function. Further information may be gained by actually observing the other professions in action. Their performance can give a more accurate idea about what they do than a verbal explanation. When the understanding about the role and function of the profession is gained, the next step is to communicate about the ideals for which each profession strives (Mosey, 1986). Over time, this approach will lead to a developing body of information from which clear hypotheses can be extracted for future proposals and projects. This process can lead to development of special training emphasis, and ultimately build a cadre of people who can collaborate. This systematic approach enables the professionals to gain a larger knowledge of their own profession as well as others (Dunn and Boyle, 1994). In Chakravorty's study, it was noted that seven (33.3\%) 
of the 21 general practitioners had, at some stage during their training, visited a hospital occupational therapy department. The other reason for the general practitioners being better informed, according to the study, was that in the community the occupational therapists often liaise with them when treating their referred patients (Chakravorty, 1993).

In 1988 Gilfoyle wrote that occupational therapy's immediate task was to define its capability and that knowledge and technology were the primary resources for that definition. The author stated that the magnitude of occupational therapy as a recognized profession is directly dependent on the degree of its scientific progress. Future directions must, according to Gilfoyle, support scientific endeavors respective to the therapeutic use of occupation, and each practitioner must commit to the application of science to practice (Gilfoyle, 1988).

Allen and Cruckshank (1977) modified Cruckshank's My Biggest Problem Today Inventory (MBPTI) which was administered to 100 randomly selected occupational therapists. The most commonly indicated "bothersome problem" was "Getting other professionals to understand and respect the role of occupational therapy" (Allen and Cruckshank, 1977, p.562). The most bothersome problem and tenth in order of frequency involved gaining the understanding of other professionals. The researchers gave several reasons for this outcome such as:

1. Occupational therapists are not successful in explaining their diverse and dissimilar functions to other professionals.

2. Occupational therapists are insecure because of the lack of technical knowledge and therapeutic skills. 
3. Occupational therapists frequently find themselves within foreign systems without enough knowledge of how to evaluate systems and work effectively within them (Allen and Cruckshank, 1977).

Allen and Cruckshank argue that these possibilities could be dealt with by educational methods and might be considered a responsibility of the professional curricula, as well as demonstration of the effectiveness of occupational therapy - its specific and unique contributions in various areas of health care (Allen and Cruckshank, 1977). The focus in communicating and cooperating with other health professions appeared in the survey to be dealing with staff members, colleagues, other professionals in the team, significant others, on a mutually respectful basis - respectful of each other's goals and options. The second most "bothersome problem" was found to be in this area. Allen and Cruckshank suggests that "the profession of occupational therapy, which justifiably prides itself on its knowledge and application of interpersonal relationships, might emphasize this at the colleague level as well as at the client level "(Allen and Cruckshank, 1977, p.562-563).

\section{Cooperation Between Health Care Professionals}

The occupational therapy process usually takes place within the context of a team of other professionals and all team members must communicate with each other in a somewhat structured and organized manner to be effective (Mosey, 1986). Communication between occupational therapy personnel and other members of the health care system is critical to the growth and acceptance of the profession. Through exchange of information and ideas with other groups, occupational therapy personnel 
gain the exposure that is necessary for achieving understanding, awareness, and respect (Krupnick, 1985). The purpose of a good communication is to: provide clear and objective data, share and problem solve with other team members so that the client receives optimal care, provide the necessary justification for the cost of evaluation and intervention, and document the occupational therapy process (Mosey, 1986).

Previous occupational therapy loyalty to the medical model has historic roots. The profession's need for acceptance and survival within the medical world and society's acceptance of occupational therapy authority have been major factors in the profession's development as an allied medical field (Gilfoyle, 1984). Demands on the profession and within the present health environment require the ability to communicate effectively with a diverse number of audiences. As professionals within a large health care system, occupational therapists must be able to deliver their message to physicians, administrators, insurance providers, clients and families (Krupnik, 1985). In the year 1987, occupational therapy was not licensed in many states in the United States. This was due to the difficulties the profession had convincing politicians that a unique professional service was provided by the profession. "This is especially problematic during lobbying activities when other professional groups who are already licensed view us as competitors with lower status" (Parham, 1987, p.555).

In the Herzberg model (1966 and 1974), certain aspects of a job were associated with job satisfaction. The motivation factors such as: work itself, recognition, achievement, responsibility and advancement were categorized as variables related to the content of the job (Bordieri, 1988). In 1982, Emner and Stephens used Herzberg's model to examine factors affecting the job satisfaction of state vocational rehabilitation 
personnel. By categorizing statements made by workers about their jobs, Emner and Stephens determined that two factors, co-workers' relationships and the nature of the work, were positively related to job satisfaction and thus, were seen as incentives by this group. Based on the post Scheffe test $(\mathrm{p}<.05)$, the achievement responsibility and interpersonal relations were rated highest (Bordieri, 1988).

\section{The Client's Benefits of Increased Knowledge between Health Care Professions}

Health care has a unique ethical responsibility to patients (Yerxa, 1995) as the profession serves and is responsible to both society and the social system. One of the profession's obligations to the clients is to be accountable, to provide evidence in regard to the nature of the services provided and effectiveness of such service (Mosey, 1986).

Interdisciplinary cooperation among health care professions is essential in order to serve the clients properly (Yerxa, 1995). The fact that the professions tend to work differently at their various functions in three arenas of health care - medical, psychosocial and developmental - makes comprehensive explanation of services difficult (Allen and Cruckshank, 1977).

As society moves into a more holistic era, understanding the interaction between all of the pieces of a specialist's knowledge is important. Expansion of health care professions assists the development of expert knowledge within each specialty. This, however, can cost difficulties when coordinating the services of many independent specialists and result in problems meeting the needs of clients (Gage, 1995). "Communication skills are particularly important in dealing with patients, the public, and other health care professionals" (Richards.1990, p. 6). 
Numerous studies substantiate the need for health care professionals now and in the future. "...it is difficult to project accurately the number and types of health occupation employees that will be needed over the next decade because of the changes taking place in technology, health care and ethics legislation, as well as current health care issues" (Richards, 1990, p.1). The National Council of Vocational Education (1989) reported an overall increase of $15-20 \%$ in the number of health care employees needed in the United States of America in the next decade (Richards, 1990).

In 1993, Chakravorty wrote, "it is encouraging to find that awareness is better among the general practitioners. In recent years, more responsibility for community rehabilitation has been entrusted to general practitioners. Their awareness of the service will enable them to help patients in the community following early discharge from hospital" (Chakravorty, 1993, p.285).

In the article, Chakravorty gives an example in which one of the general practitioners, who came to know of the service late, quoted the mother of a clumsy (movement disorder) child. The mother wrote that her son, aged 13 years, would have been much improved if he had had occupational therapy much earlier. She was convinced that there were others like her son who could be helped but, like her and her husband, were unaware of the occupational therapy service (Chakravorty, 1993).

The author states that it was possible that if the general practitioner had been aware of the function and availability of occupational therapy, the child might not have had to wait for several years before coming under occupational therapy care. Such a lack of knowledge may affect many patients who would benefit from occupational therapy. It 
can be said that knowledge of the service is an essential prerequisite for maximum use of every specialized treatment (Chakravorty, 1993).

\section{Theoretical Approach}

\section{Theoretical Perspectives}

The Model of Human Occupation (MOHO) proposed by Kielhofner in 1985 is based on theories that had their beginnings in the philosophical assumptions of the founders of the profession in the early 20 th century and was immeasurably influenced by the work of Mary Reilly (1962-1974) who developed the occupational behavior model (Levy, 1993; Kielhofner, 1992).

The Model of Human Occupation describes human beings as open systems that evolve and undergo different forms of growth, development and change through an ongoing interaction with the external environment (Levy, 1993). That it is through activity - active engagement with the environment - that the human being becomes what she/he is (Sabonis - Chafee, 1989).

There are two major premises underlying Model of Human Occupation. First, all individuals are open systems both influenced by and influencing the environment in which they exist; and second, the mind and body are interrelated and cannot be regarded as separated parts. Given these two assumptions, the Model of Human Occupation provides a structure for understanding a person's interaction with his or her environments through activity or occupational behavior (Sabonis -Chafee, 1989).

The concept of an interacting system is a key element because it focuses on the relationship between two separate complex systems - the person and the environment. 
To manage the complexity of a person, the model identifies three subsystems, volition, habituation and mind - brain - body performance (Kielhofner and Forsyth, 1997).

Volition is composed of an underlying energy source and a set of internal images. The energy source is believed to be the human's urge to explore and control the environment. The motivation to act is determined by internal images; personal causation, values and interests (Kielhofner, 1992). Personal causation is the person's belief in their ability to use their own skills effectively, the belief in being in control and the capability to achieve success. Values are the person's internal images of good, right and importance (Kielhofner, 1995). "They provide a sense of obligation to participate in certain occupations that are culturally sanctioned, and help the person experience a sense of connection to the social group" (Levy, 1993, p.78). Interests are generated from the experience of satisfaction in occupational behavior and pleasure in participating in those activities (Kielhofner, 1995 ; Levy, 1993).

Habituation is made up of two sets of images: roles and habits. Roles are images that persons hold about the positions they occupy in various social groups and of the obligations that go along with these positions. Role balance is the degree to which the person is able to integrate life roles into a satisfying and meaningful pattern of living. Roles have an internal component (the way in which a person perceives and acts on the person's role) and external components (the expectations that the society identifies with the role) (Kielhofner, 1995 ; Levy, 1993). Habits are images that trigger routine performances in lesser spheres of every day life, such as the routines with work or activities of daily living (Kielhofner, 1992). 
Performance is composed of skills and the constituents of skills. There are three types of skills: perceptual motor skills, process skills and communication/ interaction skills (Kielhofner, 1992). Constituents of skills are the underlying structures used for skilled performance; symbolic, neurologic and musculoskeletal. The person receives, processes, and reacts to stimuli from the environment. These two systems affect each other and are called the interaction (Levy, 1993).

The interaction of the individual with the environment is influenced by the status of the three subsystems. The human is a system performing in an environment composed of four layers:

1. Objects, which are the materials and artifacts that individuals use to perform tasks.

2. Tasks, which refer to both serious and playful situations for performance in the environment.

3. Social groups, which select and organize the tasks that individuals perform.

4. Culture, the groups that are available to and valued by the individual, (Kielhofner, 1992; Levy, 1993).

The interaction takes place through intake, which is when a person receives stimuli/energy from the environment. The person's processing of stimuli is called throughput which happens when a person organizes, evaluates, or makes perceptions meaningful. The person's resultant actions are called output, which occurs when he or she acts upon the environment. The last consideration is feedback, or information about the effect of the person's action. Feedback provides data to enable the person to adapt or 
adjust the action when the effects of previous actions are undesirable (Kielhofner, 1985; Sabonis - Chafee, 1989).

The organism viewed presupposes that in dealing with a complex living system there is a continual exchange between elements both within the system under study or influenced by the acquired goals of the system. Kielhofner suggests that a clear realization of this fundamental difference between open system thought and closed system thought is basic to solving the complex philosophical questions facing occupational therapy (Kielhofner, 1986 ; Sabonis - Chafee, 1989).

The approach emphasizes the organic and functional relationship between parts and the whole being. It maintains that person is a whole, an interaction of physical, psychological, environmental and social elements, and not just their sum. If any element or subsystem is negatively affected, a disruption or disturbance will be reflected throughout the whole (Sabonis -Chafee, 1989).

Occupational therapy works in cooperation with all health professions in the health care system. There is no need to apologize for the difference in philosophy but rather take pride in the profession's orgasmic approach. This approach provides a unique service to clients; it supports internal as well as external change. Although external changes are readily identifiable, internal changes are difficult to substantiate (Sabonis - Chafee, 1989). Occupational therapists' attitudes and behaviors reflect other health professional subsystems, volition, habituation and performance (Gilfoyle, 1984). Values become the essence of occupational therapy's philosophy because they describe what we do along with what is unique about our profession. Occupational therapy's values are reflected in the profession's belief in a person's ability to influence his or her 
own state of health through the use of occupation. The person's value system emerges from our rational knowledge of occupation and its intuitive knowledge of the purposefulness of the occupational process. Because the profession's values have profound influence on what the professionals do, this is a matter of great concern for the profession and association. During transformation, the value system will change; however, the professional must not let external demands dictate those changes. Rather, they should change because the profession continues to seek the truth of its values. Professional values grow from the search for truth, and during the transformation the individual must act on the values of the profession's history, and must continue to seek the meaning and truth of the present professional (Gilfoyle, 1984).

Society judges occupational therapy by the outcome of the behavior and communication of the occupational therapists. Therefore, the occupational therapists' day-to-day practice must reflect the profession's value system. The study of values continually clarifies the power of our profession, and at the same time, recognizes that the profession and society are in a continual interactive process (Gilfoyle, 1984).

\section{Short Summary of the Literature Review}

Occupational therapy in Iceland is a young profession and not well known. In a cooperation between health care professions it is important to have information about the knowledge and resources that other health care professions have. This applies to occupational therapists as weli as others (Palmadottir, 1996).

There has been little research on how other professions view occupational therapy. A first step to gain that understanding is to investigate the current attitudes of 
other professions to occupational therapy (Chakravorty, 1992; Kaur, et. al., 1996). According to a survey done by Kaur, Seager and Orrell in 1996, there is a general lack of understanding about occupational therapy and suggests that there needs to be a raising of awareness about the role of occupational therapy in the mental health unit amongst other disciplines (Kaur, et. al., 1996).

In 1991 Chakravorty carried out a study that examined the "awareness" of hospital consultants and general practitioners of occupational therapy. The survey also compared the levels of "awareness" between these two groups. This study showed that awareness of this service was still lacking in about $50 \%$ of the general practitioners and $70 \%$ of the hospital consultants (Chakravorty, 1993).

In an older survey (1977), Allen and Cruckshank found out that the most common "bothersome problem" indicated by occupational therapists was "Getting other professionals to understand and respect the role of occupational therapy" (Allen and Cruckshank, 1977, p.562). Allen and Cruckshank argued that these possibilities could be dealt with by educational methods and might be considered a responsibility of the professional curricula, as well as demonstration of the effectiveness of occupational therapy - its specific and unique contributions in various areas of health care (Allen and Cruckshank, 1977).

The aim in the health care field is: to provide clear and objective data; share and problem solve with other health care professional team members so that the client receives optimal care; provide the necessary justification for the cost of evaluation and intervention, and document the occupational therapy process (Mosey, 1986). 
Society judges occupational therapy by the outcome of the behavior and communication of the occupational therapists. Occupational therapists' attitudes and behaviors reflect other health professional subsystems, volition, habituation and performance (Gilfoyle, 1984). 


\section{Chapter III}

\section{Research Procedures}

\section{Methodology}

This study assesses the attitudes and knowledge of students in four health care professions towards occupational therapy in Iceland. All the students were in their last year in medicine, nursing, physical therapy and social work at the University of Iceland.

An attitude measurement questionnaire was constructed to be used to survey attitudes and knowledge of medical students, nursing students, physical therapy students, and social work students toward occupational therapy in Iceland. Gunnhildur Gisladottir, the author of this proposal, developed the instrument in Iceland. To ensure the reliability of the instrument, it was written in Icelandic, translated to English, and again to Icelandic by a different translator. The original version of the attitude measurement and the second version were compared to ensure that the questions had remained the same. To support validity and reliability, the survey was pilot tested before the scale was administered.

The information gained from this attitude measurement is expected to lead to a fuller understanding of the knowledge and attitudes that these four groups of health profession students have toward occupational therapy. 


\section{Research Questions}

The survey was conducted in order to answer the following three research questions:

1. What knowledge do Icelandic medical, nursing, physical therapy and social work students have about occupational therapy in Iceland?

2. What are the attitudes of Icelandic medical, nursing, physical therapy and social work students towards occupational therapy in Iceland?

3. What changes occurred among the students in the four groups of health care professions regarding knowledge and attitudes after reading a fact-sheet?

\section{Subjects}

This is a descriptive study in the form of a survey. Participants were academic students at the University of Iceland. The students were all in their last year of study in medicine, nursing, physical therapy and social work.

The population size was as follows:

\begin{tabular}{lr} 
Medical students: & 30 \\
Nursing students: & 60 \\
Physical therapy students: & 20 \\
Social work students: & 11 \\
\hline Total size & 121 \\
\hline
\end{tabular}

These unbalanced numbers among the groups occurred because of the limitations of each educational program in the University of Iceland. 
The attitude scale was used for the entire population in their last year of health care education. It was presumed that some of the students would not be present the day of the survey and that others would not volunteer.

The subjects who participated in the study were all volunteers. Computer coding each questionnaire instead of using names upheld the subjects' confidentiality.

\section{Experimental Design}

The survey instrument was constructed to assess the attitudes and knowledge of four groups of health care profession students toward occupational therapy in Iceland. The target group was health care profession students: medical, nursing, physical therapy and social work.

The measurements were made in two questionnaires, form A (Appendix B) and form B (Appendix D). In form A, the students answered questions about their current knowledge and attitude toward occupational therapy. A fact-sheet (Appendix C) identifying the philosophy, theoretical background, skills, roles, and work area of occupational therapy was prepared and given to the students between completing form A and form B. In order to find out whether the fact-sheet had an impact on the students' knowledge and attitudes, form $\mathrm{B}$ contained the same questions as form $\mathrm{A}$, with few exceptions, and two additional questions.

The underlying theory for this procedure was the Model of Human Occupation where the three subsystems were activated: volition, habituation and mind-brain-body performance. By giving the students a fact-sheet (input) the students were motivated, influenced and taught new things. In form B (output) the students were able to answer 
the same questions as in form A using their new knowledge (Kielhofner and Forsyth, 1997).

This study used a descriptive design with a Likert measurement scale. The Likert scale is considered reliable when used with a rough ordering of people with regard to a particular attitude. The five measurements were: Strongly agree, Agree, Uncertain, Disagree, and Strongly disagree. For scoring purposes, the five statements were given the weights of 1 for "Strongly agree," and 5 for "Strongly disagree" (Oppenheim, 1966).

\section{Data Collection Technique}

\section{$\underline{\text { Pilot Test }}$}

Before the scale was completed for the target group, a pilot test, under optimal conditions, was presented to a group of health care students. The pilot test included 17 individuals that were representative of the target group, all health care students in their first year at the University of Iceland. The participants were asked to fill out the instrument to determine the time it took for completion. They were informed of the purpose of the instrument, and asked to offer any additional comments.

The pilot test was followed by a qualitative evaluation debriefing session in which the 17 subjects who participated in the pilot study were asked to provide feedback regarding the clarity of each item. The participants were asked to critique the instrument and to determine if there were any problems in the questions' structure, style and directions and make any other recommendations relevant to the overall quality of the instrument. 
No weaknesses were evident in the pilot test results and therefore the survey instrument was used in its original form. It was established that the reliability of the instrument was acceptable (Benson and Clark, 1982).

\section{Questionnaire}

The population was 121 students. A large sample helps ensure that the responses of few subjects do not distort the results of the quantitative evaluation.

To maximize the return rate, the questionnaire was given to the students during class time. The questionnaire was also given to small groups in the hospitals where some of the students were doing fieldwork.

The researcher requested permission to conduct the survey in the four academic health departments of the University of Iceland. The researcher contacted the head of each University department regarding the class time for questionnaire distribution. Permission was also acquired from the persons in charge of the different departments of the hospitals where students were in fieldwork.

An introduction was written on a paper and read to the students (See Appendix A). This was done to assure that the students received the same instructions even though an introduction was made separately for each student group. In the introduction a brief explanation of the study and the students' role in it was given. The students were reassured that permission was obtained from the University of Iceland to conduct the survey and that their participation in the study was voluntary and strictly confidential. The students were also reassured that their participation in this survey was not going to affect their grades and that there was no penalty for them if they did not participate. 
The procedure was as follows:

1. Read the instructions for the students.

2. Hand out the pre-test for the students to fill out.

3. Hand out the fact-sheet with information about Occupational Therapy for the students to read.

4. Hand out the post-test for the students to fill out (form B). The post-test included the same questions that were in form $\mathrm{A}$ in section 4,5 and 6 and two additional questions. Sections 1,2 and 3 were not included in form B of the instrument.

The students were asked to read every question carefully and fill out the forms in an appropriate way. The forms were then gathered after completion.

\section{Instrument}

The attitude scale (form A) is comprised of 23 items. Each item identified the health care student's attitude and knowledge toward occupational therapy in Iceland. Eight out of 23 items are scored on a five-point scale ranging from strongly agree (one point) to strongly disagree (five points). The instrument includes six sections:

Section A - Your background and acquaintance of Occupational Therapy, which includes three questions concerning gender, profession and acquaintance with occupational therapy.

Section B - Knowledge, which includes seven questions, all on a Likert scale, one partly open-ended. All the questions concern the information the students had about occupational therapy. If the students answered "no" to question number four, 
regarding information given in their study, they were asked to turn to question number six. The same applied to a negative answer in question number six, regarding field trips to occupational therapy departments, then the students were asked to turn to question number eight. Therefore, it was possible that the students only answered five questions in this section.

Section C - Cooperation, which includes five questions, four on a Likert scale, concerning whether the students thought they had enough information to work with occupational therapists and one regarding changes in cooperation, with four items with two possibilities for answer, increased or decreased.

Section D - Attitude, which includes five questions, four on a Likert scale concerning the students attitude towards occupational therapy and one question where the students are asked to rank the professions according to importance from 1 to 5 .

Section E - The Future, which includes three questions regarding the students' view on knowledge and cooperation with occupational therapists in the future. The students were asked to put a circle around the appropriate number on a scale from 1 to 8 .

Form $\mathrm{B}$ of the instrument is similar to form $\mathrm{A}$ but sections $\mathrm{A}$ and $\mathrm{B}$ of form $\mathrm{A}$ have been left out as this information has already been gathered. Two questions are added to the form $\mathrm{B}$. Those are two questions about how the fact sheet changes the students' ideas of occupational therapy.

The instrument should provide a clarification on the health care students' opinions of occupational therapy in Iceland. 


\section{$\underline{\text { Statistical Analysis }}$}

All data analysis was carried out using the SPSS computer software. Results were considered statistically significant at the $\mathrm{p}<.05$ level.

Descriptive statistics including means, standard deviations, frequencies and percentages were calculated to describe the attitudes and knowledge of four groups of health care profession students toward occupational therapy. These techniques also examine the accuracy of data entry and missing values. Chi-square tests were used to compare the four groups on the demographic variables of knowledge questions.

The pre-test and differences scores on cooperation, attitude and future were compared among the four groups using one way analysis of variance to determine differences. For significant tests, Tukey's post hoc procedure at a $5 \%$ level was performed on all pairs of means to determine which groups were different from one another. The $t$ test was used to compare pre and post items for the whole sample of the individual groups separately, since the subjects were their own control group.

\section{Limitations of the Study}

1. Only the students who were available in the specified time period were able to complete the questionnaire.

2. The results of this data can only be generalized to the population of Icelandic students.

3. Unknown bias may have been present when using volunteers. 


\section{Chapter IV}

\section{$\underline{\text { Results }}$}

\section{Demographic Data}

This study surveyed four groups of Icelandic health care students regarding attitudes and knowledge of occupational therapy in Iceland. These four groups were medical, nursing, physical therapy and social work students. The population was 121 students and 101 students participated in this survey. There were occasions when subjects did not respond to a particular question, which is reflected in the number reported for each question.

The form A questionnaire was divided into five sections:

$$
\begin{aligned}
& \text { A - Your background and acquaintance with occupational therapy } \\
& \text { B - Knowledge } \\
& \text { C-Cooperation } \\
& \text { D - Attitude } \\
& \text { E-The Future }
\end{aligned}
$$

The following sections are named accordingly.

Section A - Your background and acquaintance with occupational therapy.

Section A consisted of three questions regarding gender, study and acquaintance with occupational therapy. 
There were 83 female $(82.2 \%)$ and 18 male (17.8\%) subjects in the sample, 22 medical students $(21.8 \%), 54$ nursing students $(53.5 \%), 18$ physical therapy students $(17.8 \%)$, and seven social work students $(6.9 \%)$.

All the subjects had heard about occupational therapy. Twenty students $(19.8 \%)$ had heard about occupational therapy at work, 18 students (17.8\%) in conversation, 16 students $(15.8 \%)$ in the school and 14 students (13.9\%) during fieldwork. Thirteen students $(12.9 \%)$ had heard about occupational therapy from a friend or family, seven students $(6.9 \%)$ in the media, and two students $(2.0 \%)$ when a friend or a family member was being treated by an occupational therapist. None of the students had first heard about occupational therapy while they were themselves being treated by an occupational therapist. Eleven students $(10.9 \%)$ answered that they had heard about occupational therapy on some other occasion. These other occasions were specified as being: not remembered by five subjects $(5.0 \%)$, in high school by two subjects $(2.0 \%)$ and in an other health care educational program by two subjects $(2.0 \%)$. Two subjects $(2.0 \%)$ got acquainted with the occupational therapy profession in an educational introduction for high schools held by the University of Iceland. 


\section{Section B - Knowledge.}

This section determines the students' knowledge of occupational therapy in Iceland, if the four health care student groups have received information about occupational therapy and if the information was sufficient. In Table 1, the results from the students' answers to the questions in this section are shown as frequencies and percentages.

Section B consisted of seven questions with three answering options: "Yes", "No" and "Do not know." Only those who gave the answers "yes" or "no" are included in Table 1. The answer "don't know" is not included when calculating the percentages. 
Table 1

Frequencies and Percentages on Knowledge Questions Answered by Four Health Care

Student Groups Regarding Occupational Therapy

\begin{tabular}{|c|c|c|c|c|c|c|c|}
\hline Question & & & $\begin{array}{l}\text { Yes } \\
\text { q. } \%\end{array}$ & $\begin{array}{l}\mathrm{N} \\
\text { Freq. }\end{array}$ & No $\%$ & $\begin{array}{l}\text { Chi- } \\
\text { square }\end{array}$ & p-value \\
\hline \multirow{5}{*}{$\begin{array}{l}\text { Was there information } \\
\text { about occupational } \\
\text { therapy in your } \\
\text { curriculum? }\end{array}$} & Medical & 21 & 95.5 & 1 & 4.5 & \multirow{5}{*}{16.95} & \multirow{5}{*}{$.001^{*}$} \\
\hline & Nursing & 44 & 81.5 & 10 & 18.5 & & \\
\hline & Physical therapy & 16 & 88.9 & 2 & 11.1 & & \\
\hline & Social work & 2 & 28.6 & 5 & 71.4 & & \\
\hline & Total & 83 & 82.2 & 18 & 17.8 & & \\
\hline \multirow{5}{*}{$\begin{array}{l}\text { Do you think the } \\
\text { information in the } \\
\text { curriculum was } \\
\text { sufficient? }\end{array}$} & Medical & 9 & 50.0 & 9 & 50.0 & \multirow{5}{*}{7.47} & \multirow{5}{*}{.279} \\
\hline & Nursing & 14 & 38.8 & 24 & 63.2 & & \\
\hline & Physical therapy & 8 & 53.3 & 7 & 46.7 & & \\
\hline & Social work & 1 & 100.0 & 0 & 0.0 & & \\
\hline & Total & 32 & 44.4 & 40 & 55.6 & & \\
\hline \multirow{5}{*}{$\begin{array}{l}\text { Were field trips to } \\
\text { occupational therapy } \\
\text { departments a part of } \\
\text { your study? }\end{array}$} & Medical & 11 & 50.0 & 11 & 50.0 & \multirow{5}{*}{11.29} & \multirow{5}{*}{$.010^{*}$} \\
\hline & Nursing & 29 & 54.7 & 24 & 45.3 & & \\
\hline & Physical therapy & 17 & 94.4 & 1 & 5.6 & & \\
\hline & Social work & 3 & 42.9 & 4 & 57.1 & & \\
\hline & Total & 60 & 60.0 & 40 & 40.0 & & \\
\hline \multirow{5}{*}{$\begin{array}{l}\text { Were the field trips } \\
\text { informative? }\end{array}$} & Medical & 5 & 100.0 & 0 & 0.0 & \multirow{5}{*}{12.84} & \multirow{5}{*}{$.046^{\star}$} \\
\hline & Nursing & 20 & 76.9 & 6 & 23.1 & & \\
\hline & Physical therapy & 13 & 86.7 & 2 & 13.3 & & \\
\hline & Social work & 2 & 100.0 & 0 & 0.0 & & \\
\hline & Total & 40 & 83.3 & 8 & 16.7 & & \\
\hline \multirow{5}{*}{$\begin{array}{l}\text { Do you know the } \\
\text { working areas of } \\
\text { occupational therapy? }\end{array}$} & Medical & 20 & 100.0 & $\overline{0}$ & 0.0 & \multirow{5}{*}{5.39} & \multirow{5}{*}{.495} \\
\hline & Nursing & 43 & 86.0 & 7 & 14.0 & & \\
\hline & Physical therapy & 15 & 93.8 & 1 & 6.2 & & \\
\hline & Social work & 6 & 100.0 & 0 & 0.0 & & \\
\hline & Total & 84 & 91.3 & 8 & 8.7 & & \\
\hline \multirow{5}{*}{$\begin{array}{l}\text { Do you understand the } \\
\text { roles and functions of } \\
\text { occupational therapy? }\end{array}$} & Medical & 20 & 100.0 & 0 & 0.0 & \multirow{5}{*}{5.87} & \multirow{5}{*}{.438} \\
\hline & Nursing & 48 & 96.0 & 2 & 4.0 & & \\
\hline & Physical therapy & 16 & 94.1 & 1 & 5.9 & & \\
\hline & Social work & 5 & 100.0 & 0 & 0.0 & & \\
\hline & Total & 89 & 96.7 & 3 & 3.3 & & \\
\hline \multirow{5}{*}{$\begin{array}{l}\text { Do you think } \\
\text { occupational therapy is } \\
\text { related to another health } \\
\text { care profession? }\end{array}$} & Medical & 15 & 78.9 & 4 & 21.1 & \multirow{5}{*}{15.88} & \multirow{5}{*}{$.014^{*}$} \\
\hline & Nursing & 34 & 77.3 & 10 & 22.7 & & \\
\hline & Physical therapy & 16 & 100.0 & 0 & 0.0 & & \\
\hline & Social work & 3 & 100.0 & 0 & 0.0 & & \\
\hline & Total & 68 & 82.9 & 14 & 17.1 & & \\
\hline
\end{tabular}


Eighty-three $(82.2 \%)$ students agreed that there had been information about occupational therapy in their curriculum (see Table 1). A Chi-square test performed to see if the percent that agreed differed among the four groups was significant, $\mathrm{p}<.001$. The greatest percentage who agreed that they had received information about occupational therapy in their curriculum was $95.5 \%$ for medical students, followed by $88.9 \%$ for physical therapy and $81.5 \%$ for nursing students. Only $28.6 \%$ of social work students said they had received information about occupational therapy in their curriculum.

Thirty-two (44.4\%) of the 72 students that answered "yes" or "no" said that the information given in their curriculum was sufficient. There was no significant difference found among the four groups of students, $\mathrm{p}=.279$, regarding whether or not the information about occupational therapy given in their curriculum was sufficient.

Significant differences were found among the four student groups for the question if there had been field trips in the curriculum, $\mathfrak{p}=.01$. Seventeen physical therapy students (94.4\%) stated that field trips to occupational therapy departments were a part of their study, while only $54.7 \%$ of nursing students, $50 \%$ of medical students, and $42.9 \%$ of social work students said so. In the question that asked if the visits had been informative, $83.3 \%$ of the sample that answered "yes" to previous question said the visits were informative.

Eighty-four of the students $(91.3 \%)$ stated that they knew the working areas of occupational therapy. All the medical and social work students agreed to this question, 43 nursing students $(86.0 \%)$ and 15 physical therapy students $(93.8 \%)$ agreed. There was no significant difference found among the four health care student groups, $\mathrm{p}=.495$. 
Eighty-nine of the students $(96.7 \%)$ said that they knew the different roles and functions of occupational therapy. All of the medical students (100\%) said yes to this question. So did $48(96.0 \%)$ of the 50 nursing students, $16(94.1 \%)$ of the 17 physical therapy students and all of the 5 social work students (100\%). There was no significant difference found among the groups, $\underline{p}=.438$.

Sixty-eight of the sample $(82.9 \%)$ thought that occupational therapy is related to another health care profession. A significant difference was found among the four groups on whether or not occupational therapy is related to another health care profession, $\mathrm{p}=.014$. One hundred percent of physical therapists and social work students said "yes" but only $78.9 \%$ of medical students and $77.3 \%$ of nursing students did.

The students who thought that occupational therapy is related to another health care profession were asked to name the related professions. Sixty-three $(92.7 \%)$ out of 68 students named one or more professions they thought related to occupational therapy. Thirty-three students (48.5\%) out of 68 thought that occupational therapy and physical therapy are closely related. Five students $(7.4 \%)$ responded that occupational therapy is related to nursing. Four students $(5.9 \%)$ thought that occupational therapy is most related to developmental therapy. Sixteen students $(23.5 \%)$ responded that occupational therapy is related to more than one profession. Seven students $(10.3 \%)$ indicated that occupational therapy is related to both physical therapy and nursing and four students (5.9\%) indicated a relationship with physical therapy and developmental therapy. Two students $(2.9 \%)$ stated that occupational therapy is related to nursing, physical therapy and developmental therapy and two students $(2.9 \%)$ stated both physical therapy and 
speech therapy to be related to occupational therapy. One student out of 68 said there is a relationship between occupational therapy and psychology.

\section{Section C-Cooperation.}

This section asked the students about their expectations toward cooperation with occupational therapists and if the students think they had enough information to be able to work with occupational therapists.

Section $\mathrm{C}$ measures how much information the four student groups have on cooperation with occupational therapists. There are four statements with five options each based on a Likert scale where 1 is the lowest value representing "Strongly agree" and 5 is the highest value representing "Strongly disagree." An analysis of variance was carried out on the answers regarding cooperation between the student's profession and occupational therapists. The results are shown in Table 2. In section $\mathrm{C}$ there was also one question with four items giving the students two options regarding each item. The results from this question are not included in Table 2, instead they are discussed in the text following Table 2. 
Table 2

Analysis of Variance on Agreement on Cooperation Questions Answered by Four

Health Care Student Groups Regarding Occupational Therapy

\begin{tabular}{|c|c|c|c|c|c|c|}
\hline Statement & Profession & $\mathrm{N}$ & Mean & SD & $\mathrm{F}$ & p-value \\
\hline \multirow{5}{*}{$\begin{array}{l}\text { I have enough } \\
\text { information about } \\
\text { occupational therapy } \\
\text { to understand its } \\
\text { functions as a health } \\
\text { care profession. }\end{array}$} & Medicine & 21 & 2.24 & 0.83 & \multirow{5}{*}{1.63} & \multirow{5}{*}{.188} \\
\hline & Nursing & 53 & 2.32 & 0.94 & & \\
\hline & Physical therapy & 18 & 1.89 & 0.47 & & \\
\hline & Social work & 7 & 2.57 & 0.53 & & \\
\hline & Total & 99 & 2.24 & 0.83 & & \\
\hline \multirow{5}{*}{$\begin{array}{l}\text { I expect to cooperate } \\
\text { with an occupational } \\
\text { therapist in the future. }\end{array}$} & Medicine & 22 & 2.00 & 0.87 & \multirow{5}{*}{9.35} & \multirow{5}{*}{$<.001^{*}$} \\
\hline & Nursing & 54 & 1.39 & 0.63 & & \\
\hline & Physical therapy & 18 & 1.89 & 0.83 & & \\
\hline & Social work & 7 & 2.71 & 0.76 & & \\
\hline & Total & 101 & 1.70 & 0.82 & & \\
\hline \multirow{5}{*}{$\begin{array}{l}\text { I have enough } \\
\text { information about } \\
\text { occupational therapy } \\
\text { to be able to } \\
\text { cooperate with an } \\
\text { occupational therapist. }\end{array}$} & Medicine & 22 & 2.82 & 1.10 & \multirow{5}{*}{5.30} & \multirow{5}{*}{$.002^{*}$} \\
\hline & Nursing & 54 & 2.69 & 1.06 & & \\
\hline & Physical therapy & 18 & 1.72 & 0.57 & & \\
\hline & Social work & 7 & 2.71 & 0.49 & & \\
\hline & Total & 101 & 2.54 & 1.03 & & \\
\hline \multirow{5}{*}{$\begin{array}{l}\text { I would like to change } \\
\text { the cooperation } \\
\text { between my } \\
\text { profession and } \\
\text { occupational } \\
\text { therapists. }\end{array}$} & Medicine & 22 & 2.95 & 0.58 & \multirow{5}{*}{5.82} & \multirow{5}{*}{$.001^{*}$} \\
\hline & Nursing & 54 & 2.17 & 0.97 & & \\
\hline & Physical therapy & 18 & 2.44 & 0.78 & & \\
\hline & Social work & 7 & 3.00 & 0.00 & & \\
\hline & Total & 101 & 2.45 & 0.89 & & \\
\hline
\end{tabular}

Note. $1=$ Strongly agree, $5=$ Strongly disagree

${ }^{*} \mathrm{p}<.05$ 
In section $\mathrm{C}$, regarding cooperation, the students were asked if they had enough information about occupational therapy to understand the profession's function as a health care profession. Ninety-nine students $(98.0 \%)$ gave an answer with a mean value of $2.24(\underline{\mathrm{SD}}=0.83)$ on a scale where 1 is strongly agree and 5 is strongly disagree. There were no significant differences among the health care groups, $\underline{p}=.188$.

In the responses to the statement; "I expect to cooperate with an occupational therapist in the future" a significant difference was found among the health care groups, $\mathrm{p}<.001$. Using Tukey's procedure at a $5 \%$ level, nursing students agreed significantly more $(\underline{M}=1.39)$ than medical students $(\underline{M}=2.00)$ and social work students $(\underline{M}=2.71)$ on expecting to cooperate with an occupational therapist in the future.

When questioned if the students thought they had enough information about occupational therapy to cooperate with an occupational therapist, a significant difference was found among the four groups of students, $\mathrm{p}=.002$. Tukey's procedure at a $5 \%$ level showed that the physical therapy students agreed significantly more $(\underline{\mathrm{M}}=1.72)$ to this question than the nursing students $(\underline{\mathrm{M}}=2.69)$ and the medical students $(\underline{\mathrm{M}}=2.82)$.

Sixteen of the students (15.8\%) strongly agreed and $33(32.7 \%)$ agreed to the statement that they would like to change the cooperation between their profession and occupational therapists. A significant difference was found among the four groups of students, $\underline{p}=.001$. Tukey's procedure at a $5 \%$ level showed that nursing students agreed significantly more $(\underline{M}=2.17)$ to this statement than medical students $(\underline{M}=2.95)$.

The statement, I would like to change the cooperation between my profession and occupational therapists included a question asking in which way the agreeing students would like to change the cooperation in four areas: education, interaction, 
cooperation and information. The students were given two possibilities for each area, "increased" or "decreased." All students $(\underline{n}=49)$ answering this question checked "increased" in the areas: education $(\underline{n}=49)$, interaction $(\underline{n}=49)$, cooperation $(\underline{n}=49)$ and information $(\underline{n}=47)$. A fifth possibility was open-ended where the students could mention any other option that came into their mind. None of the students used this option.

\section{Section D-Attitude.}

The statements in this section were meant to discover the view the four health care student groups had on occupational therapy in Iceland. The students were asked to identify their opinions on the need for occupational therapy among the health care professions and if their own profession and occupational therapy were meant to complement each other.

Section D consisted of four statements with five options each based on a Likert scale where 1 is the lowest value representing "Strongly agree" and 5 is the highest value representing "Strongly disagree." An analysis of variance was done on the answers regarding the attitude of the four student groups towards occupational therapy. The results are shown in Table 3 . In section $\mathrm{D}$ there was also one question where the students were asked to rate the importance of five health care professions where number 1 is the most important, number 2 the second most important and so on to number 5 . These results are not included in Table 3 but are discussed in the text following the table. 
Table 3

Analysis of Variance on Agreement on Attitude Questions Answered by Four Health Care Student Groups Regarding Occupational Therapy

\begin{tabular}{|c|c|c|c|c|c|c|}
\hline Statement & Profession & $\mathrm{N}$ & Mean & $\mathrm{SD}$ & $F$ & p-value \\
\hline \multirow{5}{*}{$\begin{array}{l}\text { My profession and } \\
\text { occupational therapy } \\
\text { have much in } \\
\text { common. }\end{array}$} & Medicine & 22 & 2.41 & 0.96 & \multirow{5}{*}{9.87} & \multirow{5}{*}{$.001^{*}$} \\
\hline & Nursing & 54 & 1.81 & 0.89 & & \\
\hline & Physical therapy & 18 & 1.67 & 0.59 & & \\
\hline & Social work & 7 & 3.43 & 0.79 & & \\
\hline & Total & 101 & 2.03 & 0.96 & & \\
\hline \multirow{5}{*}{$\begin{array}{l}\text { My profession and } \\
\text { occupational therapy } \\
\text { are meant to } \\
\text { complement each } \\
\text { other. }\end{array}$} & Medicine & 22 & 2.27 & 1.20 & \multirow{5}{*}{1.74} & \multirow{5}{*}{.165} \\
\hline & Nursing & 53 & 2.23 & 1.40 & & \\
\hline & Physical therapy & 18 & 2.00 & 1.03 & & \\
\hline & Social work & 7 & 3.29 & 1.25 & & \\
\hline & Total & 100 & 2.27 & 1.30 & & \\
\hline \multirow{5}{*}{$\begin{array}{l}\text { I think there is a need } \\
\text { for occupational } \\
\text { therapy among the } \\
\text { health care } \\
\text { professions. }\end{array}$} & Medicine & 22 & 1.09 & 0.29 & \multirow{5}{*}{0.20} & \multirow{5}{*}{.895} \\
\hline & Nursing & 54 & 1.11 & 0.32 & & \\
\hline & Physical therapy & 18 & 1.17 & 0.38 & & \\
\hline & Social work & 7 & 1.14 & 0.38 & & \\
\hline & Total & 101 & 1.12 & 0.33 & & \\
\hline \multirow{5}{*}{$\begin{array}{l}\text { I think occupational } \\
\text { therapy is a strong } \\
\text { profession. }\end{array}$} & Medicine & 22 & 2.77 & 0.97 & \multirow{5}{*}{2.56} & \multirow{5}{*}{.059} \\
\hline & Nursing & 52 & 2.17 & 0.96 & & \\
\hline & Physical therapy & 18 & 2.22 & 0.94 & & \\
\hline & Social work & 7 & 2.71 & 0.49 & & \\
\hline & Total & 99 & 2.35 & 0.96 & & \\
\hline
\end{tabular}

Note. $1=$ Strongly agree, $5=$ Strongly disagree

${ }^{*} \underline{p}<.05$ 
In the statement, "my profession and occupational therapy have much in common," a significant difference among the four student groups was found, $\mathrm{p}=.001$. Tukey's procedure $(5 \%$ level $)$ showed that physical therapy students $(\underline{\mathrm{M}}=1.67)$ and nursing students $(\underline{M}=1.81)$ agreed significantly more to this statement than both the medical students $(\underline{M}=2.41)$ and the social work students $(\underline{M}=3.43)$. It also showed that the medical students agreed more with this statement than the social work students.

When the students were asked if they thought there is need for occupational therapists among the health care professions, the whole sample answered either with "Strongly agree" or "Agree." Twelve students (11.9\%) agreed and 89 (88.1\%) agreed strongly. This resulted in the mean of 1.12 with the standard deviation of 0.33 . There was not a significant difference among the four student groups, $\underline{p}=.895$.

In the statements, "My profession and occupational therapy are meant to complement each other" and "I think occupational therapy is a strong profession," there were no significant differences found in answers among the four student groups.

Only two social work students ranked the health care professions according to importance. Other students agreed on the ranking of the health care professions. They considered the medical profession to be the most important health care profession, nursing the second most important. Physical therapy came in third place, occupational therapy in fourth and social work in last place. 
Section E - The future.

This section consists of statements the four health care student groups were asked on how they expect their connection with occupational therapists will be in the future and how the students expect their knowledge of occupational therapy will be.

Section E consisted of three statements with a scale from 1 ("Very little") to 8 ("Very much"). An analysis of variance was done on the statements regarding the four student groups' future knowledge of occupational therapy. The results are in Table 4 .

Table 4

Analysis of Variance on Agreement on Future Questions Answered by Four Health Care Student Groups Regarding Occupational Therapy

\begin{tabular}{|c|c|c|c|c|c|c|}
\hline Statement & Profession & $\mathrm{N}$ & Mean & SD & $\mathrm{F}$ & p-value \\
\hline \multirow{5}{*}{$\begin{array}{l}\text { My knowledge of } \\
\text { occupational therapy } \\
\text { today is } \\
\text { on the scale } 1-8\end{array}$} & Medicine & 20 & 5.30 & 0.92 & \multirow{5}{*}{2.52} & \multirow{5}{*}{.062} \\
\hline & Nursing & 54 & 4.93 & 1.44 & & \\
\hline & Physical therapy & 18 & 5.83 & 1.34 & & \\
\hline & Social work & 7 & 4.71 & 0.95 & & \\
\hline & Total & 99 & 5.15 & 1.34 & & \\
\hline \multirow{5}{*}{$\begin{array}{l}\text { My knowledge of } \\
\text { occupational therapy } \\
\text { after I begin work } \\
\text { within the health care } \\
\text { field will be on the } \\
\text { scale } 1-8 \text {. }\end{array}$} & Medicine & 21 & 5.67 & 1.02 & \multirow{5}{*}{0.63} & \multirow{5}{*}{.599} \\
\hline & Nursing & 53 & 5.89 & 1.48 & & \\
\hline & Physical therapy & 18 & 6.17 & 1.20 & & \\
\hline & Social work & 6 & 5.50 & 1.05 & & \\
\hline & Total & 98 & 5.87 & 1.31 & & \\
\hline \multirow{5}{*}{$\begin{array}{l}\text { At work my } \\
\text { professional } \\
\text { connection with } \\
\text { occupational therapy } \\
\text { will be } \\
\text { on the scale } 1-8\end{array}$} & Medicine & 20 & 4.65 & 1.50 & \multirow{5}{*}{4.96} & \multirow{5}{*}{$.003^{*}$} \\
\hline & Nursing & 51 & 5.73 & 1.79 & & \\
\hline & Physical therapy & 16 & 6.31 & 1.01 & & \\
\hline & Social work & 6 & 4.17 & 1.47 & & \\
\hline & Total & 93 & 5.49 & 1.70 & & \\
\hline
\end{tabular}

Note. $1=$ Very little, $8=$ Very much.

${ }^{*} \underline{p}<.05$ 
In the statement, "my knowledge of occupational therapy today...," 99 students answered with a mean of 5.15 and standard deviation of 1.34 . There was no significant difference among the groups, $\mathrm{p}=.662$.

No significant difference was found among the four student groups regarding their perception of their knowledge of occupational therapy after they begin work within the health care field, $\mathrm{p}=.599$.

A significant difference was found among the four health care student groups in the statement concerning professional connection to occupational therapy in the future, $\mathrm{p}=.003$. Tukey's procedure at a $5 \%$ level showed that physical therapy students expected significantly greater connection $(\underline{\mathrm{M}}=6.31)$ in work with occupational therapists than the expectations of the social work students $(\underline{M}=4.17)$ and the medical students $(\underline{\mathrm{M}}=4.62)$.

\section{$\underline{\text { Post Test - Form B }}$}

When the students had completed this questionnaire (Form A) they were asked to read a short fact sheet (Appendix C) about occupational therapy in Iceland. Having read the fact sheet they were handed a second questionnaire (Form B, Appendix D) for completion. The second questionnaire was split into three sections that are the same as the last three sections in the first questionnaire with two questions added to the last section. The questionnaire in form $\mathrm{B}$ was divided into three sections:
A - Cooperation
B - Attitude
$\mathrm{C}$ - The future 


\section{Section A-Cooperation.}

This section asked the students about their expectations towards cooperation with occupational therapists and if the students think they had enough information to be able to work with occupational therapists. Section A measures how much information on cooperation with occupational therapists that the four student groups have.

Section A consisted of four statements with five options each based on a Likert scale where 1 is the lowest value representing "Strongly agree" and 5 is the highest value representing "Strongly disagree." An analysis of variance was done in the answers regarding cooperation between the student's profession and occupational therapists. The results are shown in Table 5. In section A, there was also one question with four items giving the students two options regarding each item. The results from this question are not included in Table 5, instead they are discussed in the text following Table 5.

Each pair of question from forms $\mathrm{A}$ and $\mathrm{B}$ were compared with $t$ tests for the whole sample and for each student group separately to evaluate the effect of the factsheet on their answers. A positive difference (Form A - Form B) indicates more agreement after reading the fact-sheet, while a negative difference indicates less agreement. As shown in Table 5, $t$ tests were performed on the results of the answers in the pre-test and post-test regarding cooperation between the student's profession and occupational therapists. 


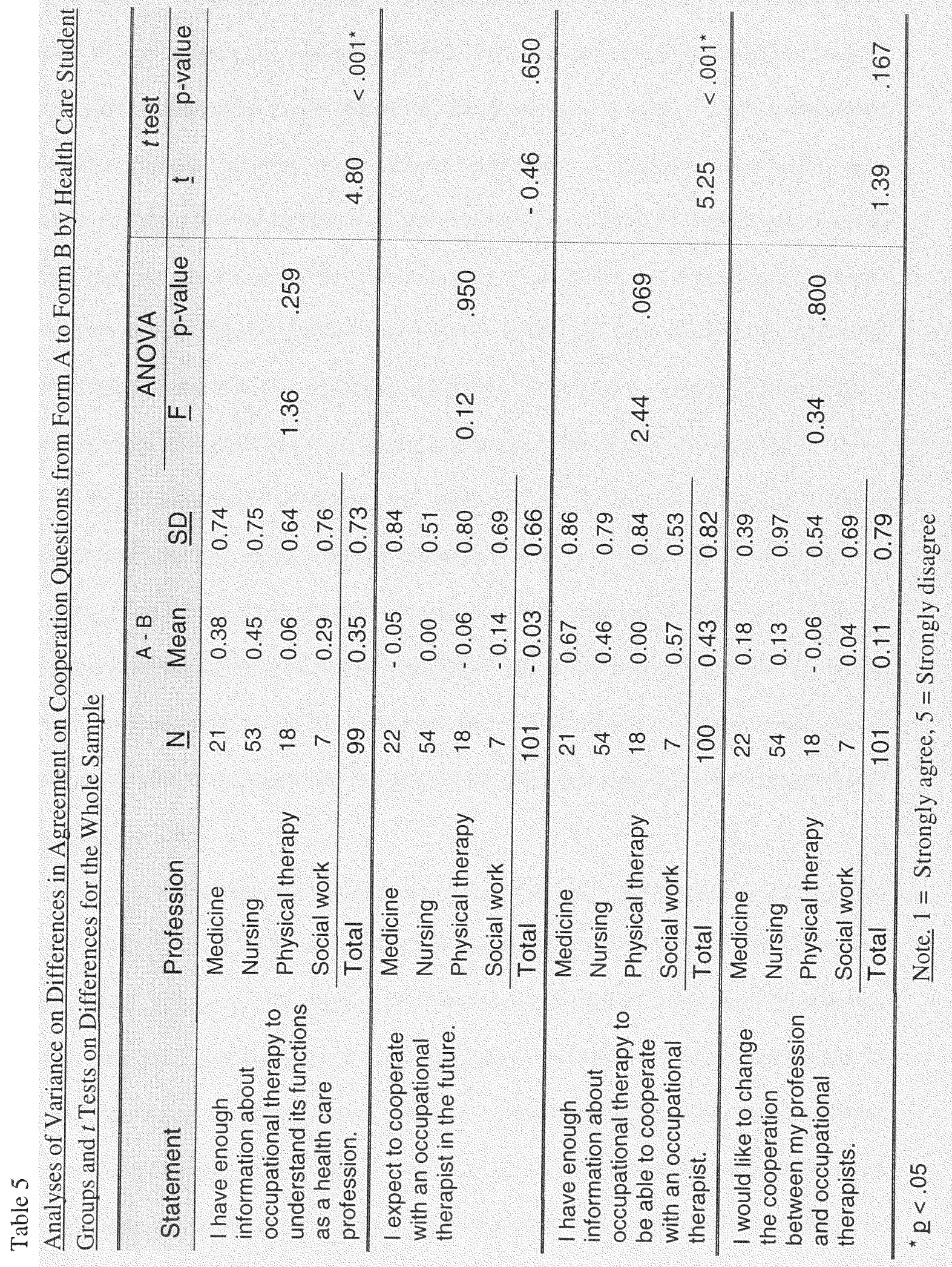


One way analyses of variance on the mean differences (Form A - Form B) of the results in the cooperation section showed that none of the four groups answered significantly different from the others. In the statement, "I have enough information about Occupational Therapy to be able to understand its functions as a health care profession," there was no significant difference found in the means from forms A and B among the four groups of health care students, $\mathrm{p}=.259$. A $t$ test was used to compare the differences in answers for the whole group before and after reading the fact-sheet concerning this statement. A significant difference was found $\mathfrak{p}<.001$, with the sample agreeing more after reading the fact-sheet (mean difference $=0.35$ ) than before.

In the statement regarding the students having enough information about occupational therapy to be able to cooperate with an occupational therapist, no significant differences were found among the four student groups, $\mathrm{p}=.069$. A comparison of the whole sample before and after the fact sheet was given and resulted in a significant mean increase in agreement $(\underline{M}=0.43)$ that the students had enough information about occupational therapy to be able to cooperate with occupational therapists, $\mathrm{p}<.001$.

In the statements, "I expect to cooperate with an occupational therapist in the future" and "I would like to change the cooperation between my profession and occupational therapists," no significant differences among the four groups were noted, and no change in agreement was noted from form $A$ to form $B$ for the whole sample. In the next question, the students were asked in which way the agreeing students would like to change the cooperation given four areas: education, interaction, cooperation and information. The students were given two possibilities for each area, "increased" or 
"decreased." Fifty-two students answered this question, all stating increased in the areas of education, interaction and cooperation. In the information area, 47 students answered stating, "increased" and one student stated, "decreased." An open-ended possibility of this question was giving the student the chance of mentioning some other means of changing the cooperation. None of the students used this option. Only minor changes were found between the answers from form $\mathrm{A}$ to form $\mathrm{B}$ on this question.

Section B-Attitude.

The statements in this section were meant to discover the view the four health care student groups had on occupational therapy in Iceland after reading a fact-sheet about occupational therapy. The students were asked to identify their opinions on the need for occupational therapy among the health care professions and if their own profession and occupational therapy were meant to complement each other.

Section B consisted of four statements with five options each based on a Likert scale where 1 is the lowest value representing "Strongly agree" and 5 is the highest value representing "Strongly disagree." An analysis of variance was done on the answers regarding the change in attitude of the four student groups toward occupational therapy after reading the fact-sheet. The results are shown in Table 6. A $t$ test was also done on the differences in the students' answers from form $\mathrm{A}$ to form $\mathrm{B}$ and the results are also shown in Table 6 . In section B there was also one question where the students were asked to rate the importance of five health care professions where number 1 is the most important, number 2 the second most important and so on to number 5 . These results are not included in Table 6 but are discussed in the text following the table. 


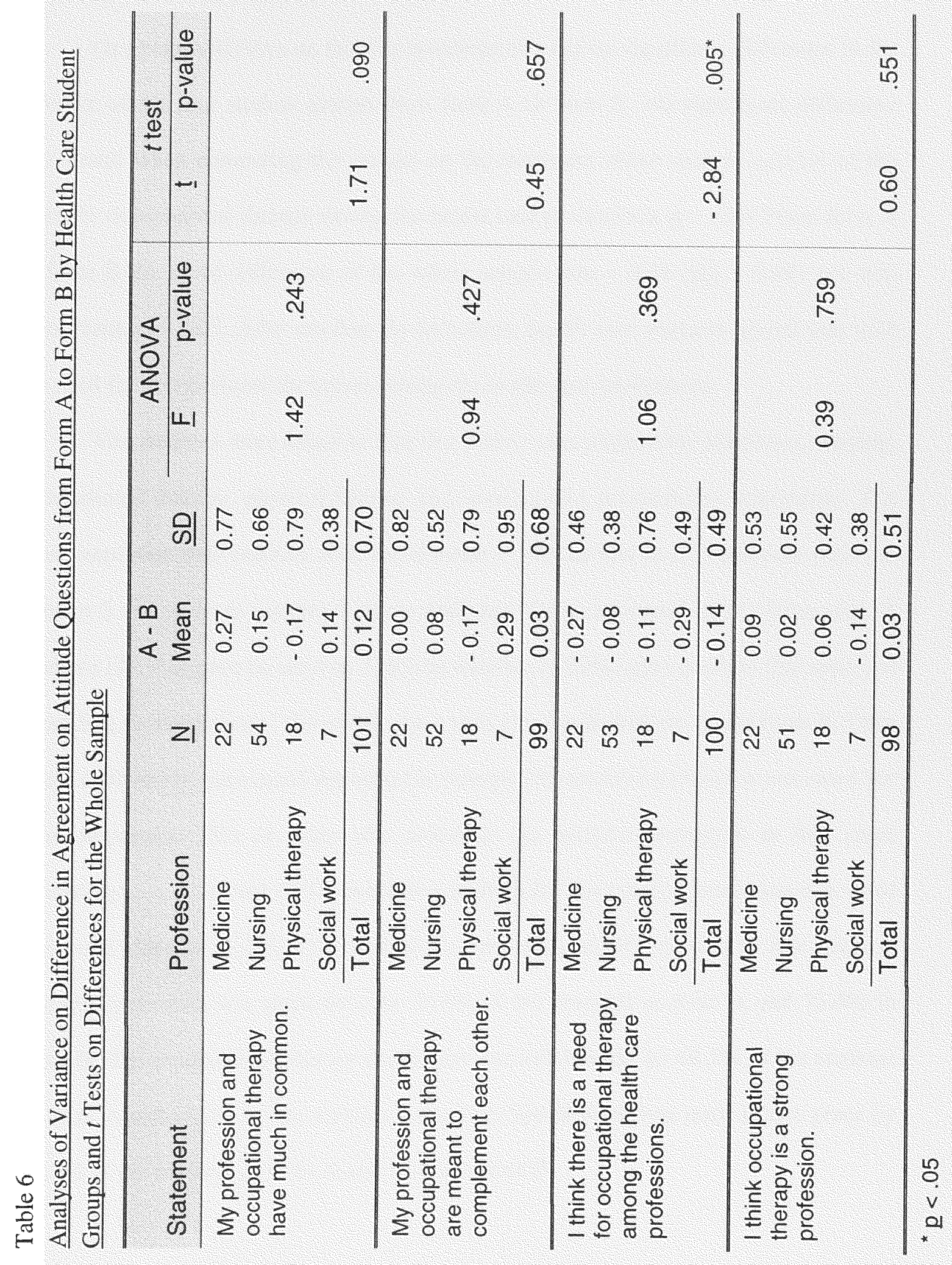


One way ANOVAs on the four questions showed no significant difference in the answers of the four student groups from form A to form B. No significant difference was found when comparing the groups on the statement about student opinion of the need for occupational therapy among the health care professions, $\mathrm{p}=.369$. From form $\mathrm{A}$ to form $\mathrm{B}$ the mean difference of the whole sample was $-0.14(\underline{\mathrm{SD}}=0.49)$ and was significant, $\mathrm{p}=.005$. After reading the fact-sheet, health care students agreed less with the need for occupational therapists among the health care professions.

The students were asked to rate five health care professions (medicine, nursing, occupational therapy, physical therapy and social work) according to importance. The most important was marked with the number 1 , the second most important with the number 2 and so on to number 5 . Sixty students (59.4\%) answered this question and 28 students (27.7\%) gave no answer. Thirteen students (12.9\%) gave answers that were not according to instructions. The results were very close in both form A and form B. Only small differences were noted between the ratings. The medical profession was rated the most important; $75 \%$ of those who answered put medical profession in first place according to form $\mathrm{A}$ and $74.1 \%$ according to form $\mathrm{B}$. The nursing profession was rated in second place by $61.7 \%$ of the students in form $\mathrm{A}$ and $63.8 \%$ in form $\mathrm{B}$. The physical therapy profession was rated third by $70.0 \%$ of the students in form $\mathrm{A}$ and $72.4 \%$ in form $\mathrm{B}$. The occupational therapy profession was rated fourth by $68.3 \%$ of the students in form $\mathrm{A}$ and $67.2 \%$ of the students in form B. Social work was rated in last place by $76.7 \%$ of the students in form $\mathrm{A}$ and $77.6 \%$ in form $\mathrm{B}$. 
The occupational therapy profession remained in the same place (fourth place) after the students had read the fact-sheet. The difference between the two forms was that 41 students on form A and 39 students on form B rated occupational therapy in fourth place.

Section $\mathrm{C}$ - The future.

Section C consisted of three statements which were the same as in section $\mathrm{E}$ on form $\mathrm{A}$ and two additional questions which were the only questions which were unique on form B. The five questions were all on the scale from 1 ("Very little") to 8 ("Very much"). Differences were calculated as Form A - Form B, so positive difference indicates less agreement after reading the fact-sheet while a negative difference indicates more agreement. Table 7 consists of the analysis of variance of the answers from form B on the questions regarding future knowledge of the four student groups on occupational therapy. A $t$ test was also done on the differences in the same questions between form A and form B. Those results are also shown in Table 7. 


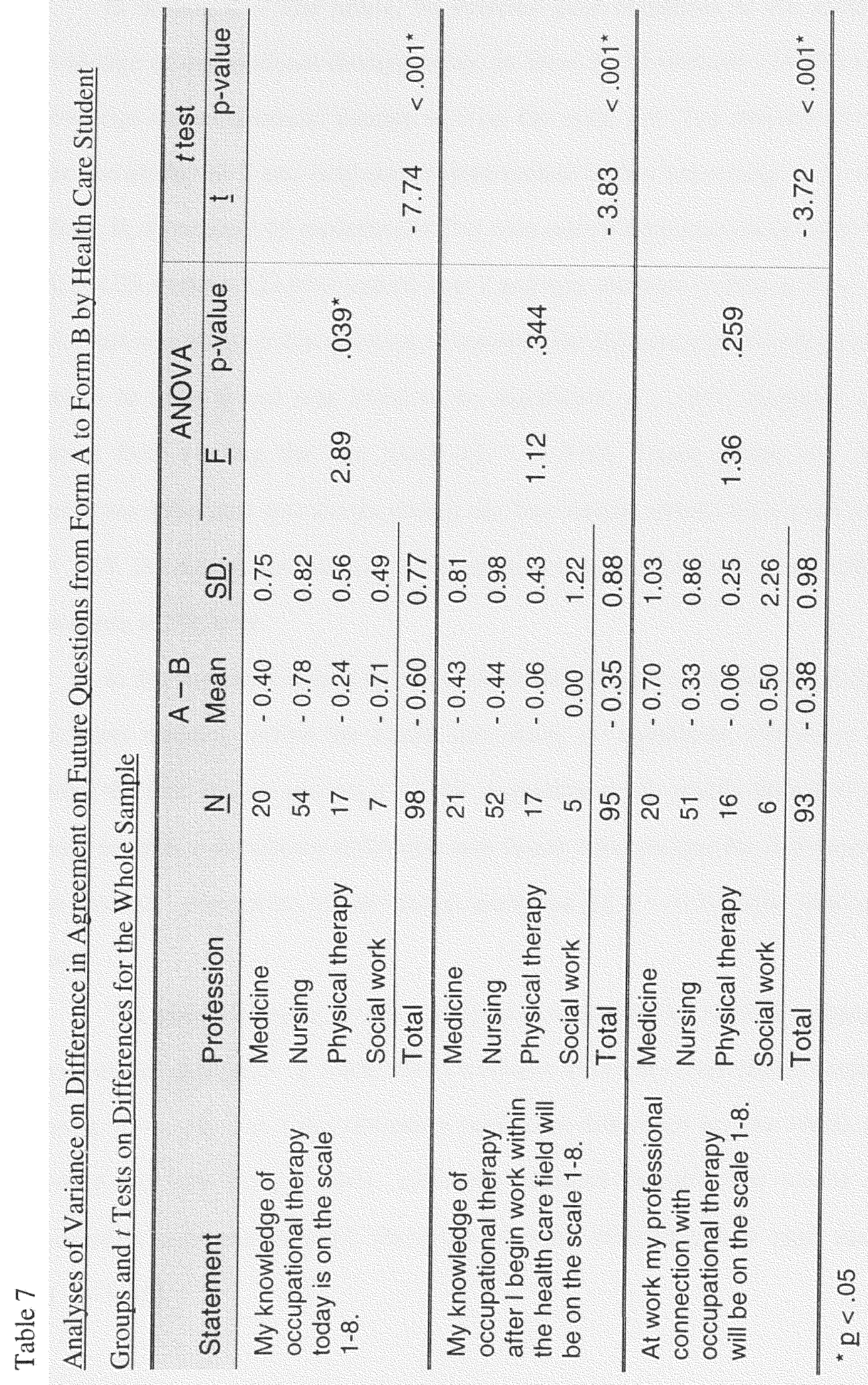


In section $\mathrm{C}$ - The future, 98 students gave responses to the statement about knowledge of occupational therapy today. In form A, 35 students $(34.7 \%)$ ranked their knowledge on occupational therapy as 6 on the scale $1-8$. Ten students $(9.9 \%)$ ranked their knowledge as 7 and only one student ranked his/her knowledge as 8 on the scale. In form $\mathrm{B}$, there were 35 students $(34.7 \%)$ who ranked their knowledge as 6 on the scale $1-8$, but 23 students (22.8\%) ranked it as 7 and two students $(2.0 \%)$ as 8 on the scale 1 8. A $t$ test was done on this question to measure the difference of the whole sample from form $\mathrm{A}$ to form $\mathrm{B}$ and was found to be significant, $\mathrm{p}<.001$. Students, as a whole, learned from reading the fact sheet $(\underline{\mathrm{M}}=-0.60)$. Using a one way ANOVA, a significant difference was shown among the four student groups from form $\mathrm{A}$ to form $\mathrm{B}$, $\mathrm{p}=.039$. No significant pairwise differences among groups were found using Tukey's procedure at $5 \%$ level.

In the statement regarding the students' knowledge of occupational therapy after they start working within the health care field, no significant difference was found among the four student groups, $\mathrm{p}=.344$. According to the results from the $t$ test for the whole sample, a significant difference was found after reading the fact-sheet, $\mathrm{p}<.001$. The students' perception of knowledge increased $(\underline{M}=-0.35)$ after reading the factsheet.

The third statement in this section was regarding the student's connection with occupational therapists at work. No significant difference was found among the four groups, $\mathrm{p}=.259$. The $t$ test showed a significant difference for the whole group from form $\mathrm{A}$ to form $\mathrm{B}, \mathrm{p}<.001$, indicating students thought they would have more connection with occupational therapists at work after they had read the fact-sheet $(\underline{M}=-0.38)$. 
In order to see the effects the fact-sheet had on each group of students separately, $t$ tests were done. The $t$ test shows if there were significant differences between the answers of each group before and after they have read the fact-sheet. Table 10 lists only the questions/statements where significant differences were found, $\underline{p}<.05$.

There were large differences in the effect the fact-sheet had on the four student groups. According to the $t$ tests the fact sheet did not significantly change any of the physical therapy students answers. The social work students showed a significant difference from form $\mathrm{A}$ to form $\mathrm{B}$ in only two of the 11 questions. The nursing students showed significant differences in five of the 11 questions. The medical students were most affected by the fact-sheet. In seven of the eleven questions that were tested the medical students showed significant differences after reading the fact sheet.

Medical, nursing and social work student groups answered two questions significantly different after reading the fact-sheet. Those questions were; "I have enough information about occupational therapy to be able to cooperate with an occupational therapist," and "My knowledge of occupational therapy today is on the scale 1-8." In both cases, the students considered their information and knowledge to have increased by reading the fact-sheet.

A significant difference was also found for both medical and nursing students on three additional statements before and after reading the fact-sheet. They agreed more to these three statements after reading the fact-sheet than they did before reading the factsheet. As shown in Table 10, these three questions all concerned their current and future information and knowledge of occupational therapy. 


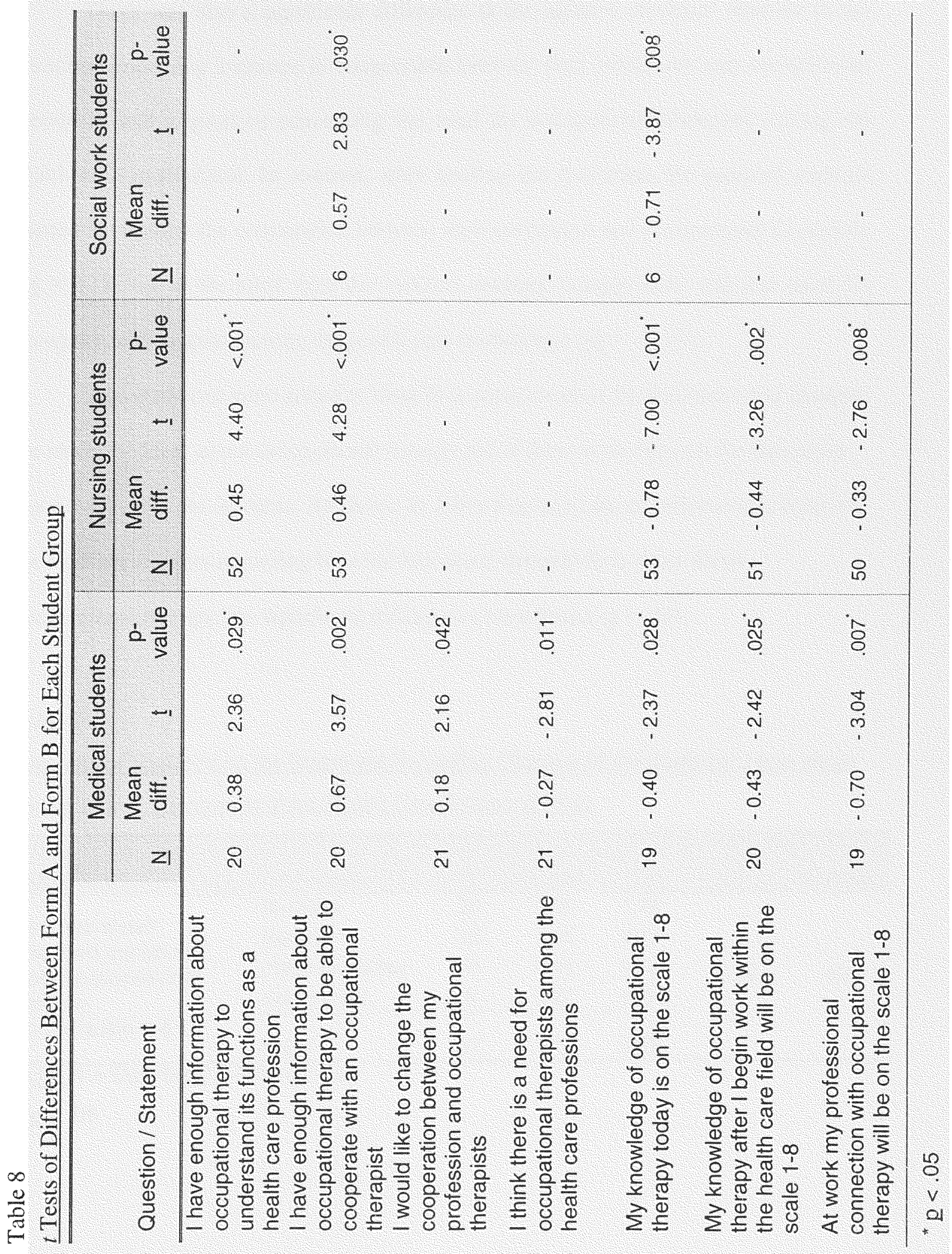


There was also a significant difference in the medical students' answers to the question concerning a change in cooperation between their profession and occupational therapists, and a question concerning the need for occupational therapists among the health care professions. In contrast, after reading the fact-sheet the medical students wanted to increase the cooperation between their profession and occupational therapists, $(\underline{M}=0.18)$ but at the same time the medical students thought there was less need for occupational therapists among the health care professions $(\underline{\mathrm{M}}=-0.27)$.

Two questions were added to form B in order to see if the fact-sheet had changed the students' ideas about occupational therapy and if there were facts on the fact-sheet that were new to the students. As shown in Table 8 an analysis of variance was done on the students answers regarding how the fact-sheet changed their ideas about occupational therapy. No significant differences were found, $\mathrm{p}=.838$.

Table 9

Analysis of Variance on the Statement Regarding Changes of the Students' Ideas about Occupational Therapy, by Four Health Care Student Groups

\begin{tabular}{|c|c|c|c|c|c|c|}
\hline Statement & Profession & $\mathrm{N}$ & Mean & SD & F & p-value \\
\hline \multirow{5}{*}{$\begin{array}{l}\text { The fact sheet } \\
\text { changed my ideas } \\
\text { about occupational } \\
\text { therapy } \\
\text { on the scale } 1-8\end{array}$} & Medicine & 20 & 3.00 & 1.78 & \multirow{5}{*}{0.28} & \multirow{5}{*}{838} \\
\hline & Nursing & 53 & 3.25 & 2.17 & & \\
\hline & Physical therapy & 18 & 2.83 & 1.86 & & \\
\hline & Social work & 6 & 3.50 & 1.64 & & \\
\hline & Total & 97 & 3.13 & 1.99 & & \\
\hline
\end{tabular}


Ninety-seven students (96.0\%) answered the statement; "The fact-sheet changed my ideas about occupational therapy..." A bar chart shown in Figure 1 demonstrates the distribution of the responses to the statement regarding the effect the fact-sheet had on the students' ideas about occupational therapy.

Figure 1 - Distribution of the results from the statement regarding changes of the students' ideas about occupational therapy.

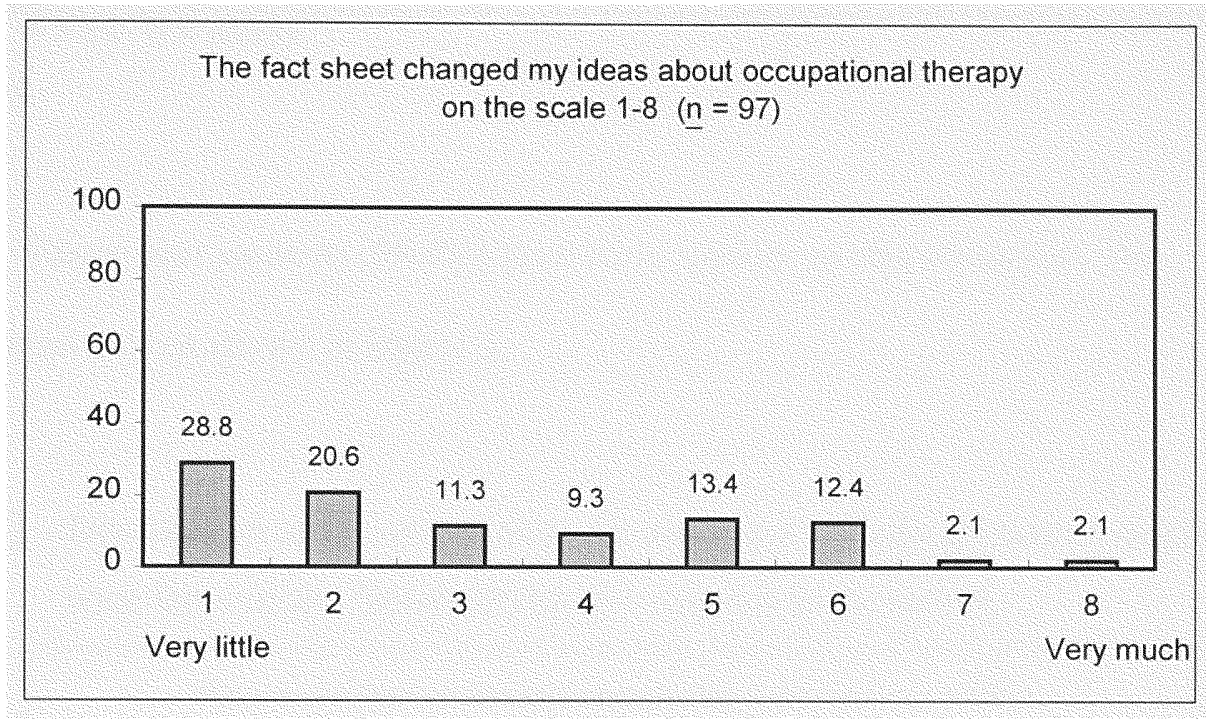

There were $49 \%$ of the students that believed the fact-sheet changed ideas very little (1) or little (2).

An analysis of variance was done for the statement regarding whether or not there were facts on the fact-sheet that the students did not know before. This was done to see if there were differences in the answers among the four student groups. The results are shown in Table 9. There was not a significant difference among the four health care student groups, $\underline{p}=.229$. 
Table 10

Analysis of Variance on the Statement Regarding Whether or not There were Facts on

the Fact-sheet That the Students Knew Before, by Four Health Care Student Groups

\begin{tabular}{|c|c|c|c|c|c|c|}
\hline Statement & Profession & $N$ & Mean & $\mathrm{SD}$ & F & $\mathrm{p}$-value \\
\hline \multirow{5}{*}{$\begin{array}{l}\text { There were facts on } \\
\text { the fact sheet which I } \\
\text { did not know before } \\
\text { On the scale } 1-8\end{array}$} & Medicine & 21 & 3.29 & 1.62 & \multirow{5}{*}{1.47} & \multirow{5}{*}{.229} \\
\hline & Nursing & 53 & 4.02 & 2.16 & & \\
\hline & Physical therapy & 18 & 3.00 & 1.78 & & \\
\hline & Social work & 7 & 3.86 & 2.48 & & \\
\hline & Total & 99 & 3.67 & 2.03 & & \\
\hline
\end{tabular}

Ninety-nine students $(98.0 \%)$ gave their opinion on this statement. The distribution was as shown in Figure 2.

Figure 2-Distribution of the results from the statement regarding whether or not there were facts on the fact-sheet that the students knew before.

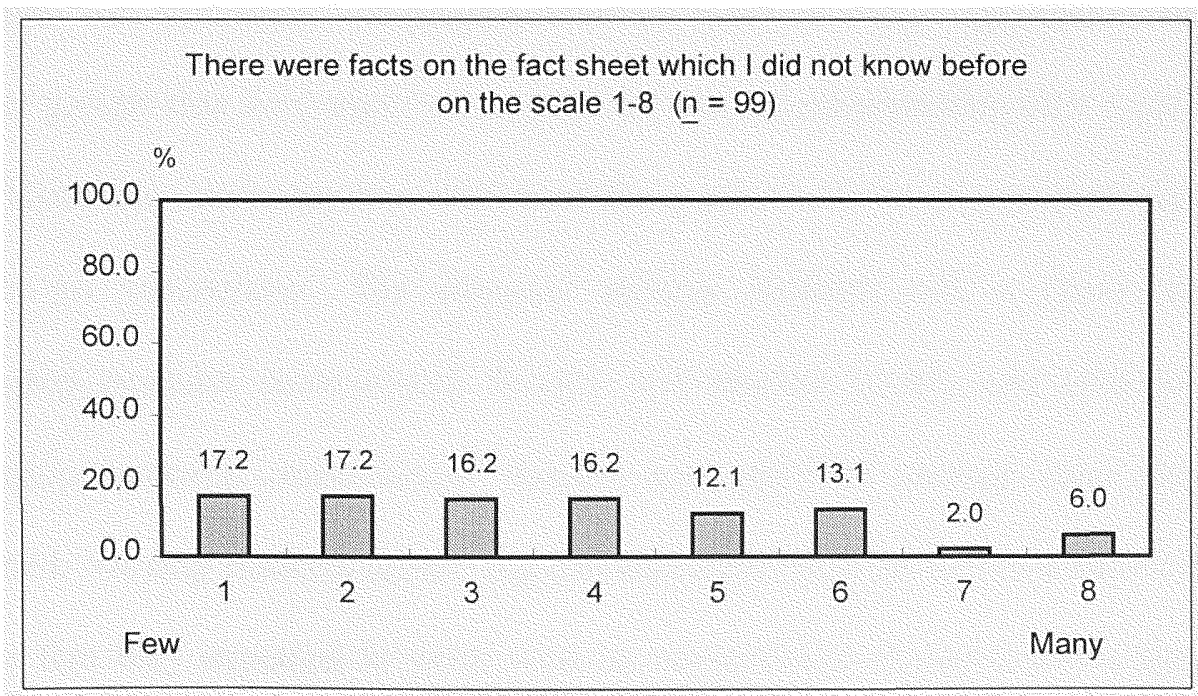


There was a uniform distribution of the answers from "few facts" (1) to "some facts" (4) on the scale. The percentage of students answering few (1) to some (4) were very close, ranging from $16.2 \%$ to $17.2 \%$.

These two statements indicate that some facts were learned but fewer opinions were changed.

\section{$\underline{\text { Summary }}$}

This study surveyed four groups of Icelandic health care students regarding attitudes and knowledge of occupational therapy in Iceland.

\section{Before reading the fact-sheet}

All the student groups had been given information about occupational therapy in their curricula. Social work students were the group that had least information given in their study-time. Fifty-six students did not think the information given in their curriculum was sufficient. The physical therapy students stated significantly more than the other groups that field trips to occupational therapy departments were a part of their study. More than three-quarters $(83 \%)$ of the students that went on field trips found them to be informative. The physical therapy students saw a more significant relationship between occupational therapy and another health care profession. The relationship between occupational therapy and physical therapy was most often mentioned. Nursing students agreed significantly more than the medical and social work students that they expected to work with an occupational therapist in the future. The physical therapy students agreed significantly more to having enough information about occupational therapy to cooperate with an occupational therapist than the nursing 
students and the medical students. Nursing students agreed significantly more than the medical students on the statement that they would like to change the cooperation between their profession and occupational therapists. Physical therapy students and nursing students agreed significantly more than the medical students and social work students that their profession and occupational therapy have much in common. Physical therapy students significantly more than the social work students and the medical students expected to have a close working relationship with occupational therapists.

After reading the fact-sheet

A significant difference was found in the sample agreeing more after reading the fact-sheet to having enough information to understand occupational therapy's functions as a health care profession and to having enough information about occupational therapy to be able to cooperate with occupational therapists than before reading the fact-sheet. A significant difference was found as the students agreed less with the need for occupational therapy among the health care professions.

In the future section, the students were found to have learned from reading the fact-sheet and to have increased their knowledge by reading the fact-sheet. After reading the students thought they would have more connection with occupational therapists. The four student groups showed no significant differences in their opinions as to whether or not the fact-sheet changed their ideas about occupational therapy. The $t$ tests of differences between forms A and B for each student group on the other hand indicated that the fact-sheet actually did influence the students. Physical therapy students changed their opinion the least from form $A$ to form B and medical students the most. 


\section{Chapter V}

\section{Discussion}

\section{$\underline{\text { Research Questions }}$}

It is interesting for the occupational therapy profession in Iceland to discover how other professions view occupational therapists. This is important in the areas of cooperation between occupational therapists and other health care professions in order to be aware of each other's skills, roles and working areas.

This study addressed three research questions: (1) What do medical, nursing, physical therapy and social work students know about occupational therapy in Iceland? (2) What attitudes do Icelandic medical, nursing, physical therapy and social work students have toward occupational therapy? (3) What changes occurred among the students in the four groups of health care professions regarding knowledge and attitude after reading a fact-sheet? The importance of the results is based on the assumption that students' beliefs may influence how the students work with occupational therapists when they finish their study and start working in a hospital or in other health care settings.

The Changes that Occurred Among the Four Student Groups Regarding Knowledge and Attitudes After Reading the Fact-sheet

Overall, the significant differences between the pre- and post-test questions were fewer than expected and I can only speculate why the fact-sheet had so little impact on 
the students' answers from pretest to posttest. The fact-sheet had the most impact on the medical students. Physical therapy students were the student group that showed the least differences in their answers between form $\mathrm{A}$ and form $\mathrm{B}$. One of the reasons could have

been that the students knew more about occupational therapy than I expected and, therefore, the fact-sheet (Appendix C) contained little information that was new to them. Another possibility is that the information on the fact-sheet was not thorough enough.

\section{Knowledge}

The first question addressed what knowledge the four groups of health care students had about occupational therapy. The results were that the students obtained knowledge about occupational therapy during their study years. This knowledge was either in the form of information about occupational therapy in their curriculum or on field trips to occupational therapy departments. In the students' opinions, field trips to occupational therapy departments were informative, the information given in the students' curricula was sufficient for only $44 \%$ of the sample. The questionnaire did not ask which kind of information on occupational therapy the students had gained during their study years, or if the information was given by occupational therapists.

Even though a majority of the students were not satisfied with the information given in their curricula, nearly all the students stated that they knew the working areas of occupational therapy and that they understood the roles and functions of occupational therapy. It was noticed that all the medical students and all the social work students stated that they understood the different roles and functions of occupational therapy. It should be taken into consideration though that individuals with the same information 
may estimate their knowledge differently. In the Kaur et. al. study from 1996, many respondents stated that they were confident that they understood the service provided by occupational therapy but according to the authors this indicated a lack of understanding about occupational therapy (Kaur et. al., 1996).

The majority of the students believed that occupational therapy is related to another health care profession. It was no surprise that almost every other student responding to this question thought occupational therapy has its closest relationship to physical therapy. In Iceland, these two professions are often compared to each other not only by people outside the health care business but sadly enough, also by professions working in the health care area. In some cases, occupational therapists and physical therapists also compare themselves in relation to study length and salary. Both of these professions are therapists but they have very different views on their clients. It was more surprising that a few of the students saw the greatest relationship between occupational therapy and the nursing professions, as these professions have traditionally not been compared. On the other hand, one might have expected that more students saw relationships between occupational therapy and psychology, but only one of the students mentioned psychology in relation to occupational therapy.

An increase was found concerning the students' knowledge of occupational therapy on the scale $1-8$, and in the statement regarding the students' knowledge of occupational therapy after beginning work within health care after reading the factsheet. The fact-sheet seemed to have an influence on the students and this was reflected in changes in the answers as the whole student group rated higher after reading the factsheet than before. Medical and nursing students were the two student groups that 
showed most changes regarding these questions. In the knowledge section, the physical therapy students did not show any changes in their answers between form A and form B. The medical students were the group that changed their answers the most between the two forms in the knowledge section. In Iceland, it is very important that the medical students know the occupational therapy profession since physicians refer clients to occupational therapists. Chakravorty found in his survey that there was a direct relationship between referral rate and the referring doctor's awareness of occupational therapy (Chakravorty, 1993).

\section{Cooperation}

Overall, all the students thought they had enough information about occupational therapy to understand its functions as a health care profession. Again, it is interesting to connect those answers to the question where $56 \%$ of the students stated that the information given in their curricula was not sufficient. The medical and nursing students were the student groups that changed their opinion the most after reading the fact-sheet. Before reading the fact-sheet, both of these student groups stated that they had enough information to understand the functions of occupational therapy as a health care profession. The fact-sheet changed the medical and nursing students' views in the way that they rated their information to be significantly more than they rated it before reading the fact-sheet. These results support the possibility that the students may be unaware of their lack of information regarding occupational therapy and only realize their limits when they are given added information about the profession. 
Nursing students were the student group that most expected to cooperate with an occupational therapist in the future and most wanted increased cooperation between their profession and occupational therapists. These results are comparable to the results from Kaur et. al. (1996). In that study the health care professions stated that nurses were the professionals who should have most communication with occupational therapists (Kaur et. al., 1996). Even though the nursing students expected cooperation with occupational therapists, they also rated that they did not have enough information about occupational therapy to be able to cooperate with an occupational therapist.

Three student groups agreed more, after reading the fact-sheet, that they had enough information about occupational therapy to be able to cooperate with an occupational therapist. These three were: the nursing, medical, and social work student groups. The physical therapy students were most likely to think they had enough information to be able to cooperate with an occupational therapist and did not change their opinion after reading the fact-sheet. Also, the physical therapy students group expected the most professional interaction with occupational therapists in the future. These statements from the physical therapy students can be connected to the previous questions where a majority of the physical therapy students were satisfied with the information given in their curriculum and they also were rated highest concerning the sufficiency of information during visits to occupational therapy departments. Four students of the sample disagreed to having enough information about occupational therapy to be able to cooperate with an occupational therapist after reading the fact-sheet while only one student disagreed to this statement before reading the fact-sheet. This 
supports the fact that students would like more information about occupational therapy in their curricula.

The Attitudes of the Four Student Groups Towards Occupational Therapy in Iceland

Before reading the fact-sheet, both physical therapy students and nursing students $(78.2 \%$ of sample) stated that their profession had much in common with occupational therapy. After the students read the fact-sheet, no differences were found among the student groups. Consequently, it is tempting to believe that the information given in the fact-sheet gave a clear statement about the skills and roles of occupational therapy. These results are similar to the Kaurs et. al. results; whereas, $88 \%$ of the sample of psychiatrics, social workers and psychologists saw occupational therapy as having overlap with other professions than their own. Only nurses saw the main overlap being with their own profession. The explanations given by Kaur et. al. were lack of understanding about the functions of occupational therapy (Kaur et. al., 1996).

An interesting change in the answers to the statement, "I think there is a need for occupational therapists among the health care professions," occurred after reading the fact-sheet. The medical students $(\underline{n}=21)$ showed a significant difference in their answers by stating after they had read the fact-sheet that there was less need for occupational therapists among the health care professions. These, of course, are disappointing results for occupational therapists to receive after having given inclusive information about the profession in a fact-sheet. Perhaps this is understandable when taken into consideration that medical students can also picture themselves working in medical model symptom reductionistic areas such as surgery, $x$-ray, ophthalmology, 
etc., where there is not an obvious need for occupational therapists. After reading the facts about occupational therapy, the medical students may have wanted to refer to areas where the physicians work and occupational therapists do not overlap.

In the statement concerning how the fact-sheet changed the students' ideas about occupational therapy, a majority of the students rated that the fact-sheet had not changed their ideas very much. These results seem opposite to what was found when comparing the answers from form $\mathrm{A}$ and form B. When looking at each student group independently, significant differences in a positive direction were found in a majority of the medical student groups' answers after reading the fact-sheet. The information the medical students have obtained during their study time has probably been at a minimum. These results confirm Chakravorty's results where the awareness of occupational therapy among physicians was around $50 \%$ of the general practitioners and $70 \%$ of the hospital consultants (Chakravorty, 1993). The nursing group and social workers' group showed only minor changes in their opinions after reading the fact-sheet. The physical therapy students were the only student group that showed no significant differences in their answers from form A to form B. Physical therapy students have good information about occupational therapy and did not gain much new knowledge by reading the factsheet. All the student groups reported that the fact-sheet did not provide significantly new information about occupational therapy. Yet, the changes in the students' answers between form $\mathrm{A}$ and form $\mathrm{B}$ indicated that some of the facts must have been new to them. When using a fact-sheet with a questionnaire, the participants may not realize the influence of the fact-sheet. The fact-sheet information may have been the reason for the differences in the students answers between the pre- and post-tests. 


\section{$\underline{\text { Recommendations }}$}

A number of limitations in the current study need to be acknowledged. First, in examining only Icelandic health care professional students, a cultural bias may be present. It would be interesting to replicate the study with health care professional students from other countries. Second, the information value of the fact-sheet could be questioned. It should be considered that the fact-sheet was developed only to use in this study and was not provided by the Icelandic Association of Occupational Therapists.

The results of this study can only be generalized to the population of Icelandic students participating in this study, and it should be taken into consideration that only seven individuals took part representing the social work student group. This sample size was large $(\underline{\mathrm{n}}=7)$ in relation to the whole social work student group population $(\underline{\mathrm{N}}=11)$. The differences among the student groups in sample size make it harder to give reliable results, especially regarding social work students with such a small sample size.

This is a study that would be interesting to repeat in five years when the University of Iceland has graduated the first two groups of occupational therapists in Iceland. By that time, occupational therapy will hopefully be better known both among the other health care profession students and also in the Icelandic society. It could show whether there would be differences in the answers from medical, nursing, physical therapy and social work students regarding attitude, knowledge and cooperation toward occupational therapy.

A similar study could question the working health care professions, physicians, nurses, physical therapists and social workers. It would be interesting to see whether it 
would give similar results to this survey. In this study though, the interest was focused on the students.

\section{$\underline{\text { Summary }}$}

Occupational therapy is a rather young profession in Iceland and not well known. It is important that all health care professions are aware of each other's skills and work areas. This knowledge is important for the benefit of professional cooperation, for the benefit of professional growth and last, but not least, for the benefit of service to the client.

The purpose of this study was to gain a better understanding of the knowledge and attitudes of four groups of health care students in medicine, nursing, physical therapy and social work toward occupational therapy in Iceland. The results of this study indicated that the four groups of students had gained some knowledge about occupational therapy in Iceland doing their University experience. Knowledge was gained either in form of class information or during visits to occupational therapy departments. Many students wanted more information about occupational therapy in their curriculum. Yet, they thought they had enough information to work with an occupational therapist. The overall attitude of the students towards cooperation with occupational therapists was positive.

The health care professions judge each other by their behavior and communication. Therefore, it is important for occupational therapists to be aware that their attitude, behavior and daily practice reflect the opinions held by other health care professions. By being open minded, showing interest and asking questions, each 
profession is able to gain information about the roles and functions of other professions. Occupational therapists cooperate with all professions in the health care system. All these professions are unique and should be proud of their philosophy and see their differences as resources for their clients, not as obstacles in interdisciplinary cooperation and cohesiveness. 


\section{References:}

Adalsteinsdottir, S. (1996). Almennar upplysingar. Haskolaarid 1996-1997. Felagsvisindadeild Haskola Islands. Reykjavik.

Allen, A.S. and Cruckshank, D.R. (1977). Perceived Problems of Occupational Therapists: A Subset of the Professional Curriculum. The American Journal of Occupational Therapy, 31, (9), 557-564.

Benson, J. and Clark, F. (1982). A Guide for Instrument Development and Validation. The American Journal of Occupational Therapy, 36, 789-800.

Blane, (1997). Health professions. In G. Scambler (ed.) Sociology as applied to Medicine $4^{\text {th }}$ edition, 212-224. London, W. B. Saunders Company Ltd.

Bordieri, J. E. (1988). Job Satisfaction of Occupational Therapists: Supervision and Managers Versus Direct Service Staff. The Occupational Therapy Journal of Research, 13, (3), 155-165.

Bucher, R. and Strauss, A. (1966). Professions in Progress. The American Journal of Sociology, 66, 325-334.

Canadian Association of Occupational Therapists. (1997). Enabling Occupation: An Occupational Therapy Perspective. CAOT Publications ACE. Ottawa. 
Chakravorty, B.C. (1993). Occupational Therapy Services: Awareness among Hospital Consultants and General Practitioners. British Journal of Occupational Therapy, $\underline{56},(\underline{8})$ 283-286.

Colman, W. (1992). Maintaining Autonomy: The Struggle Between Occupational Therapy and Physical Medicine. The American Journal of Occupational Therapy, 46 , (1), 63-70.

Creek, J. and Ormston, C. (1996). The Essential Elements of Professional Motivation. British Journal of Occupational Therapy, 59, (1), 7-10.

Dunn, W. and Boyle, M. A. (1994). A Comparison of Funding Patterns in Professional Occupational Therapy Education Programs. The American Journal of Occupational Therapy, 14,.(2), 157-168.

Gage, M. (1995). Re-engineering of Health Care: Opportunity or treat for occupational therapists? Canadian Journal of Occupational Therapy, 62, (4), 197-207.

Gilfoyle, E. M. (1988). Partnerships for the Future. The American Journal of Occupational Therapy, $42,(\underline{8}), 485-488$.

Gilfoyle, E. M. (1984). Transformation of a Profession. In the 1984 Eleanor Clarke Slagle lecture The American Journal of Occupational Therapy, 38, (9), 431-445.

Gudmundsson, M.; Erlendsson, K.; Sveinsdottir, H.; Sigurdardottir, S. and Ingolfsdottir, K. (1994). Haskoli Islands. Haskolautgafan. Kopavogi, Svansprent.hf. 
Grady, A. P. (1987). Research: Its Role in Enhancing the Professional Image. The American Journal of Occupational Therapy, $\underline{41}$, (), 347-349.

Harries, P. and Caan, A. W. (1994). What do Psychiatric Inpatients and Ward staff think about Occupational Therapy? British Journal of Occupational Therapy, 57, (ㅁ) , 219-223.

Hayden, J. (1995). Professional Socialization And Health Education Preparation. Journal of Health Education, 26, (5), 271-276.

Ingadottir, I. (1996). University of Iceland. Department of Nursing 1996-1997. Reykjavik. Haskoli Islands. Namsbraut i Hjukrun.

Kaur, D., Seager, M. and Orrell, M. (1996). Occupational Therapy? The Attitudes of Mental Health Professionals. British Journal of Occupational Therapy, 59, (7), 319322.

Kielhofner, G. and Forsyth, K. (1997). The Model of Human Occupation: an Overview of Current Concepts. British Journal of Occupational Therapy, 60 , (3), 103110.

Kielhofner, G. (1995). A Model of Human Occupation. Theory and Application. Second Edition. Williams and Wilkins.

Kielhofner, G. (1992). Conceptual Foundations of Occupational Therapy. Philadelphia. F.A. Davis Company. 
Krupnick, W. (1985). Targeting Communications. In Janette Blair and Madelaine Gray (eds.) The Occupational Therapy Manager. Maryland, Rockville. The American Occupational Therapy Association, Inc.

Lane, J. P. (1990). Commentary - Funding for Research and Training in Professional Occupational Therapy Education Programs from 1985 to 1987. The American Journal of Occupational Therapy, 10, 343-344.

Levy, L. L. (1993). Model of Human Occupation frame of reference. In H.L. Hopkins and H.D. Smith (eds.). Willard's and Spackman's Occupational Therapy, pp. 76-79. Philadelphia, J.B. Lippincott company.

Merriam-Webster's Collegiate Dictionary. (1994). Merriam-Webster Incorporated.

Mosey, A. C. (1986). Psychosocial Components of Occupational Therapy. New York. Raven Press.

Mosey, A. C. (1985). Eleanor Clarke Lecture, 1985: A Monistic or a Pluralistic Approach to Professional Identity? The American Journal of Occupational Therapy, $\underline{39}$, (8), 504-509.

Oppenheim, A. N. (1966). Questionnaire design and attitude measurement. New York, Basic Books, Inc. publishers.

Palmadottir, G. (1997). Idjuthjalfun verdur islensk fraedigrein. Stada og throun nam a idjuthjalfabraut Haskolans a Akureyri. Idjuthjalfinn, Fagblad Idjuthjalfa, 19, (2)), $14-19$. 
Palmadottir, G. (1996). Occupational Therapy Education Program in Iceland Needs and Development. WFOT Bulletin, 33, 19-23.

Parham, D. (1987). Toward Professionalism: The reflective Therapist. The American Journal of Occupational Therapy, 41, (9), 555-561.

Parker, H. J. and Chan, F. (1986). Prestige of Allied Health Professions: Perception of Occupational and Physical Therapists. Occupational Therapy Journal of $\underline{\text { Research, }}$. . (4). 247-250.

Richards, B. (1994). Health Occupational Education Teaching Competencies for the Twenty-First Century, Occupational Therapy Journal of Research, 9, (2) $), 19-44$.

Richards, B. (1990). Health Occupational Education: Avoiding Crisis or Creating Crisis. Journal of Health Occupations Education, $\underline{5}$, (2), 1-16.

Rosenberg, M. J., Hovland, C. I., McGuire, W. J., Abelson, R. P. and Brehm, J. W. (1960). Attitude Organization and Change, An Analysis of Consistency Among Attitude Components. New Haven and London, Yale University Press.

Sabonis-Chafee, B. (1989). Occupational Therapy: introductory concepts. Missoury, St, Louis. The C. V. Mosby Company.

Scullin, V. (1943). Psychiatry's Contribution to Occupational Therapy. Occupational Therapy and Rehabilitation, 22, 132-135. 
Shortell, S. M. (1974). Occupational Prestige Differences Within the Medical and Allied Health Professions. Social Science and Medicine, B, 1-9.

Yerxa, E. J. (1995). Who is the Keeper of Occupational Therapy's Practice and Knowledge? The American Journal of Occupational Therapy, 49, (4), 295-298. 
Appendix A - Introduction of the questionnaire

\section{Introduction of the questionnaire}

\section{Students}

First I would like to thank you all for your participation in this survey.

A student who is acquiring a master's degree in occupational therapy from the Florida International University does the survey.

The purpose of the study is to survey the knowledge and attitudes of four different groups of Icelandic health care professional students regarding occupational therapy in Iceland. The measurement also surveys your opinion on cooperation between your profession and occupational therapists.

Your answers are strictly confidential and will not affect your grades. The results will be analyzed as group results and answers from each individual will not be identified.

The procedure will be as follows:

a) The first questionnaire will be handed out (form A).

b) A fact sheet with information about occupational therapy will be handed out.

c) Finally you will be given the second questionnaire (form B) which includes some of the questions from form $\mathrm{A}$ and two additional questions.

After completion of the form A, please set the form aside with the front page up. Then read the fact sheet and complete form $\mathrm{B}$ and put it inside form $\mathrm{A}$.

Leave the forms on your desk when you are finished and they will be gathered.

Estimated completion time is 15 minutes.

Please ask if you have any questions.

Thank you for your cooperation. 
Appendix B - Form A, in English

Form A

Occupational Therapy; Knowledge - Cooperation - Attitude

The purpose of this questionnaire is to research the individual's attitude and knowledge of Occupational Therapy. The research is done on health care students.

Please fill out the questions to the best of your ability. If you have any doubts, ask the person who hands out the questionnaires. If you have any remarks or want to add to the questions you can do so on the last page of the form. Your answers will be strictly confidential and will have no impact on your grades.

Section A - Your Background and Acquaintance of Occupational Therapy

1 Which are you, male or female?

$\square$. Male

$\square_{2}$ Female

2 Which profession are you studying?

$\square$, Social Work

$\square$ Nursing

$\square$ Medicine

$\square_{4}$ Physical Therapy

3 Where did you first hear about Occupational Therapy? (mark only with one option)

$\square_{1}$ I have never heard of Occupational Therapy $\Rightarrow$ You do not have to continue the survey. Thank you for your participation.

$\square_{2}$ In the school

$\square_{3}$ in the media

$\square_{4}$ in conversation

$\square_{5}$ At work

$\square_{6}$ In Field Work

$\square_{7}$ From a friend or family

$\square_{8}$ When I was being treated by an Occupational Therapist

$\square$, When a friend or a family member was being treated by an Occupational Therapist

$\square_{10}$ Other: $\Rightarrow$ What? 


\begin{tabular}{|c|c|c|c|c|}
\hline & & Yes & No & $\begin{array}{l}\text { Don't } \\
\text { know }\end{array}$ \\
\hline \multirow[t]{2}{*}{4} & $\begin{array}{l}\text { Was there information about Occupational } \\
\text { Therapy in your Curriculum? }\end{array}$ & $\square_{1}$ & $\square_{2}$ & $\square_{3}$ \\
\hline & If No, turn to question 6. & & & \\
\hline 5 & $\begin{array}{l}\text { Do you think the information in the } \\
\text { curriculum was sufficient? }\end{array}$ & $\square_{1}$ & $\square_{2}$ & $\square_{3}$ \\
\hline \multirow[t]{2}{*}{6} & $\begin{array}{l}\text { Were field trips to Occupational Therapy } \\
\text { departments a part of your study? }\end{array}$ & $\square_{1}$ & $\square_{2}$ & $\square_{3}$ \\
\hline & If No, turn to question 8. & & & \\
\hline 7 & Were the field trips informative? & $\square_{1}$ & $\square_{2}$ & $\square_{3}$ \\
\hline 8 & $\begin{array}{l}\text { Do you know the working areas of } \\
\text { Occupational Therapy? }\end{array}$ & $\square_{1}$ & $\square_{2}$ & $\square_{3}$ \\
\hline 9 & $\begin{array}{l}\text { Do you understand the roles and functions } \\
\text { of Occupational Therapy? }\end{array}$ & $\square_{1}$ & $\square_{2}$ & $\square_{3}$ \\
\hline 10 & $\begin{array}{l}\text { Do you think Occupational Therapy is related } \\
\text { to another health care profession? }\end{array}$ & $\square_{1}$ & $\square_{2}$ & $\square_{3}$ \\
\hline & If yes: $\Rightarrow$ Which? & & & \\
\hline
\end{tabular}

Section C - Cooperation

\begin{tabular}{|c|c|c|c|c|c|c|}
\hline & & $\begin{array}{c}\text { Strongly } \\
\text { agree }\end{array}$ & Agree & Uncertain & Disagree & $\begin{array}{l}\text { Strongly } \\
\text { disagree }\end{array}$ \\
\hline 11 & $\begin{array}{l}\text { Thave enough information } \\
\text { about Occupational } \\
\text { Therapy to understand its } \\
\text { functions as a health care } \\
\text { profession. }\end{array}$ & $\square_{1}$ & $\square_{2}$ & $\square_{3}$ & $\square_{4}$ & $\square_{5}$ \\
\hline 12 & $\begin{array}{l}\text { I expect to cooperate with } \\
\text { an Occupational Therapist } \\
\text { in the future }\end{array}$ & $\square_{1}$ & $\square_{2}$ & $\square_{3}$ & $\square_{4}$ & $\square_{5}$ \\
\hline 13 & $\begin{array}{l}\text { I have enough information } \\
\text { about Occupational } \\
\text { Therapy to be able to } \\
\text { cooperate with an } \\
\text { Occupational Therapist }\end{array}$ & $\square_{1}$ & $\square_{2}$ & $\square_{3}$ & $\square_{4}$ & $\square_{5}$ \\
\hline
\end{tabular}




\begin{tabular}{llllll} 
I would like to change the & $\begin{array}{c}\text { Strongly } \\
\text { agree }\end{array}$ & Agree & Uncertain & Disagree & $\begin{array}{c}\text { Strongly } \\
\text { disagree }\end{array}$ \\
\hline $\begin{array}{l}\text { cooperation between my } \\
\text { profession and }\end{array}$ & & & & & \\
Occupational Therapists & $\square_{1}$ & $\square_{2}$ & $\square_{3}$ & $\square_{4}$ & $\square_{5}$
\end{tabular}

15 If you agree to the statement in question 14 , in which way would you like to change the cooperation? (Mark where appropriate)

I would like to see

a) Education: $\quad \square_{1}$ increased $\quad \square_{2}$ Decreased

I would like to see

b) Interaction: $\quad \square_{1}$ Increased

$\square_{2}$ Decreased

I would like to see

c) Cooperation: $\square_{1}$ increased

$\square$, Decreased

I would like to see

d) Information: $\square_{1}$ increased

$\square$. Decreased

e) Other: $\Rightarrow$ What?

Section D - Attitude

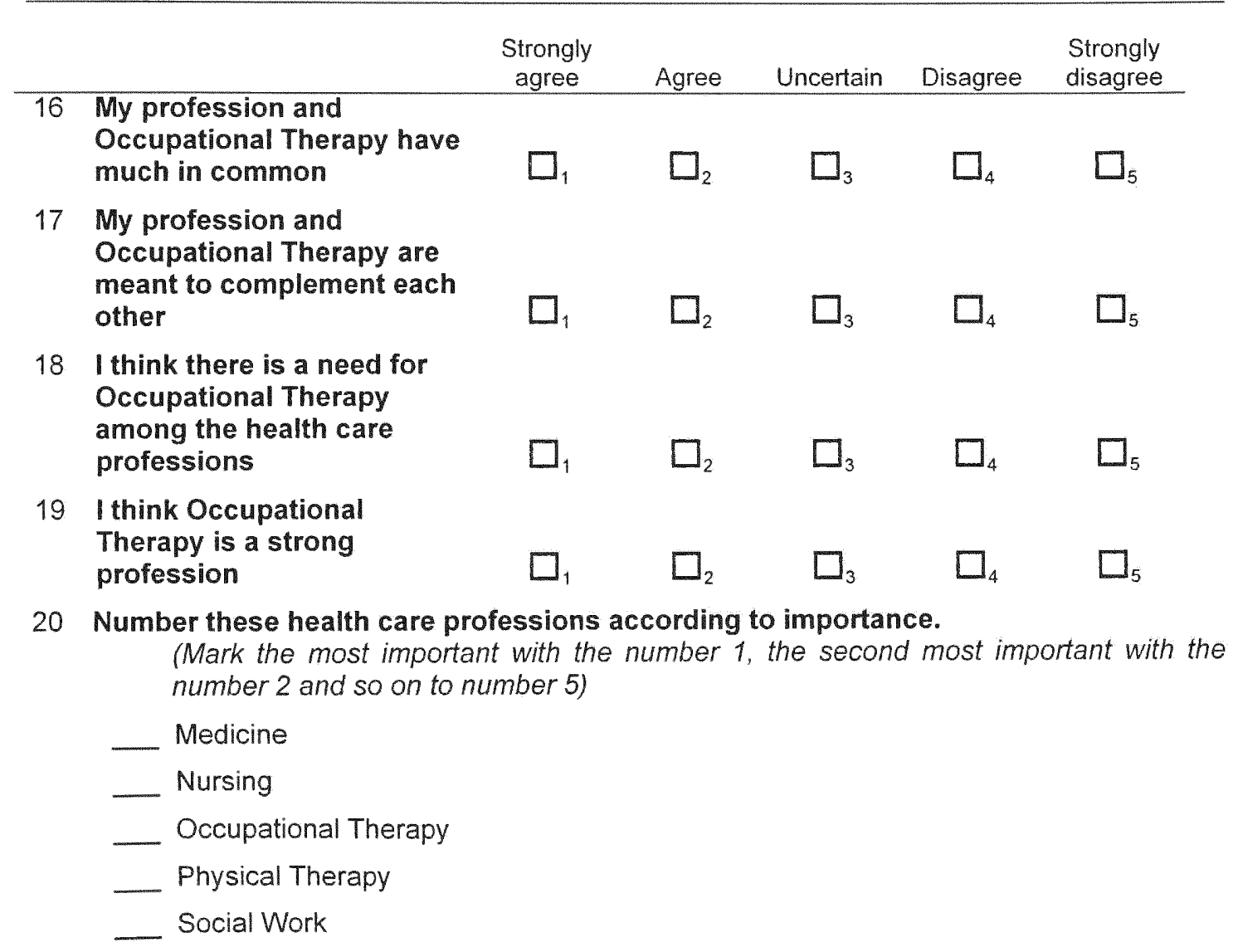


21 My knowledge of Occupational Therapy today is on the scale 1-8:

(Circle the appropriate number on the scale)

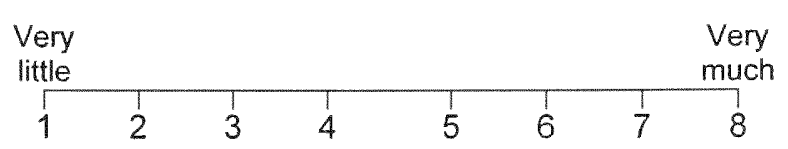

22 My knowledge of Occupational

Therapy after I begin work within the health care field will be on the scale 1-8:

(Circle the appropriate number on the scale)

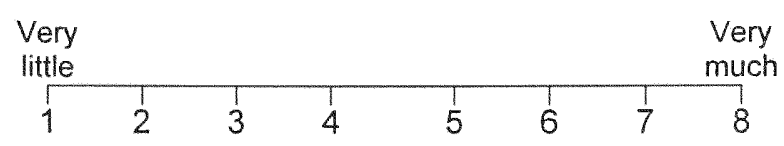

23 At work my professional connection with Occupational Therapy will be on the scale 1-8:

(Circle the appropriate number on the scale)

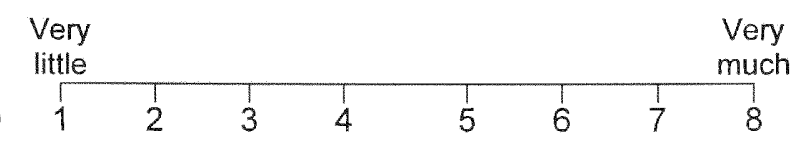

IF YOU HAVE ANY REMARKS OR WANT TO ADD TO THE QUESTIONS FILL OUT THE FOLLOWING TABLE.

\begin{tabular}{|l|l|}
\hline Question no. & Remarks \\
\hline & \\
\hline & \\
\hline & \\
\hline & \\
\hline & \\
\hline & \\
\hline & \\
\hline
\end{tabular}

Thank you very much for your participation. 
Appendix C - Fact-sheet, in English

DID YOU KNOW:

that in Iceland there are 84 practicing occupational therapists working part- or full time?

that occupational therapy as a profession developed during World War I but it has only been a health profession in Iceland for twenty years?

$\checkmark$ that in Iceland, there is one occupational therapist per 4500 persons, which is more occupational therapists per person than in any other European country?

$\checkmark$ that all of the occupational therapists working in Iceland obtained their education in other countries such as: Denmark, Norway, Sweden, U.S.A., France, Netherlands and Australia?

$\checkmark$ that in the fall 1997 an occupational therapy program started at the University in Akureyri?

$\checkmark$ that the length of the occupational therapy program is four years and the student will earn a bachelor of science in occupational therapy?

$\checkmark$ that there exists a World Federation of Occupational Therapy and Iceland is one of the members?

$\checkmark$ that occupational therapy is one of the world's fastest growing professions?

$\checkmark$ that occupational therapists work in acute-hospitals, rehabilitation centers, schools, nursing homes, diagnostic centers, district-agencies for service for disabled, centers for technical aids and provide private counseling services?

$\checkmark$ that occupational therapists assist individuals who are mentally, physically, developmentally, and/or emotionally disabled?

$\checkmark$ that occupational therapists assist individuals to develop, recover or maintain daily living, educational, leisure and working skills?

$\checkmark$ that occupational therapists assist individuals to improve motor functions, and reasoning abilities?

$\checkmark$ that occopational theraspists assist individuals to compensate for permanent loss of function?

$\checkmark$ that the goal of occupational therapy is to assist individuals in gaining independent and productive satisfying lifestyles?

$\checkmark$ that occupational performance areas include activities of daily living, work activities, and leisure activities?

$\checkmark$ that occupational therapists provide adaptive equipment to individuals with functional disabilities, i.e. wheelchairs, splints, and aids for activities of daily living (ADL)?

$\checkmark$ that occupational therapists also design and make special equipment needed at home or at work?

$\checkmark$ that occupational therapists assist the individual in adapting to the work environment after disability? They arrange employment, plan work activities, do job-training and evaluate the individual's progress.

$\checkmark$ that for more information you can contact the Icelandic Association of Occupational Therapists co/Hope Knutsson, Aesufelli 4, tel. 5573734 ? 
Appendix D - Form B in English

Form B

\section{Occupational Therapy; Knowledge - Cooperation - Attitude}

This is the second part of the research on the individuals attitude and knowledge of Occupational Therapy. The research is done on health care students.

The questions are partly the same as in form $A$.

Please fill out the questions to the best of your ability. If you have any doubts ask the person who hands out the questionnaires. If you have any remarks or want to add to the questions you can do so on the last page of the form. Your answers will be strictly confidential and will have no impact on your grades.

Section A - Cooperation

\begin{tabular}{|c|c|c|c|c|c|c|}
\hline & & $\begin{array}{c}\text { Strongly } \\
\text { agree }\end{array}$ & Agree & Uncertain & Disagree & $\begin{array}{l}\text { Strongly } \\
\text { disagree }\end{array}$ \\
\hline 1 & $\begin{array}{l}\text { Thave enough information } \\
\text { about Occupational Therapy } \\
\text { to understand its functions as } \\
\text { a health care profession. }\end{array}$ & $\square_{1}$ & $\square_{2}$ & $\square_{3}$ & $\square_{4}$ & $\square_{5}$ \\
\hline 2 & $\begin{array}{l}\text { I expect to cooperate with an } \\
\text { Occupational Therapist in the } \\
\text { future }\end{array}$ & $\square_{1}$ & $\square_{2}$ & $\square_{3}$ & $\square_{4}$ & $\square_{5}$ \\
\hline 3 & $\begin{array}{l}\text { I have enough information } \\
\text { about Occupational Therapy } \\
\text { to be able to cooperate with } \\
\text { an Occupational Therapist }\end{array}$ & $\square_{1}$ & $\square_{2}$ & $\square_{3}$ & $\square_{4}$ & $\square_{5}$ \\
\hline 4 & $\begin{array}{l}\text { I would like to change the } \\
\text { cooperation between my } \\
\text { profession and Occupational } \\
\text { Therapists }\end{array}$ & $\square_{1}$ & $\square_{2}$ & $\square_{3}$ & $\square_{4}$ & $\square_{5}$ \\
\hline
\end{tabular}

5 If you agree to the statement in question 4 , in which way would you like to change the cooperation? (Mark where appropriate)

I would like to see
a) Education:
$\square$, increased
$\square$ Decreased
b) Interaction:
$\square_{1}$ increased
$\square$ Decreased
c) Cooperation:
$\square_{1}$ Increased
$\square$ Decreased
d) Information:
$\square_{1}$ Increased
$\square_{2}$ Decreased
e) Other: $\Rightarrow$ What?

I would like to see

I would like to see

I would like to see 


\begin{tabular}{|c|c|c|c|c|c|c|}
\hline & & $\begin{array}{c}\text { Strongly } \\
\text { agree }\end{array}$ & Agree & Uncertain & Disagree & $\begin{array}{l}\text { Strongly } \\
\text { disagree }\end{array}$ \\
\hline 6 & $\begin{array}{l}\text { My profession and } \\
\text { Occupational Therapy have } \\
\text { much in common }\end{array}$ & $\square_{1}$ & $\square_{2}$ & $\square_{3}$ & $\square$ प & $\square_{5}$ \\
\hline 7 & $\begin{array}{l}\text { My profession and } \\
\text { Occupational Therapy are } \\
\text { meant to complement each } \\
\text { other }\end{array}$ & $\square_{1}$ & $\square_{2}$ & $\square_{3}$ & $\square_{4}$ & $\square_{5}$ \\
\hline 8 & $\begin{array}{l}\text { I think there is a need for } \\
\text { Occupational Therapy } \\
\text { among the health care } \\
\text { professions }\end{array}$ & $\square_{1}$ & $\square_{2}$ & $\square_{3}$ & $\square_{4}$ & $\square_{5}$ \\
\hline 9 & $\begin{array}{l}\text { Ithink Occupational } \\
\text { Therapy is a strong } \\
\text { profession }\end{array}$ & $\square_{1}$ & $\square_{2}$ & $\square_{3}$ & $\square_{4}$ & $\square_{5}$ \\
\hline
\end{tabular}

10 Number these health care professions according to importance.

(Mark the most important with the number 1, the second most important with the number 2 and so on to number 5)

Medicine

Nursing

Occupational Therapy

Physical Therapy

Social Work

Section C - The Future

11 My knowledge of Occupational Therapy today is on the scale 1-8

(Circle the appropriate number on

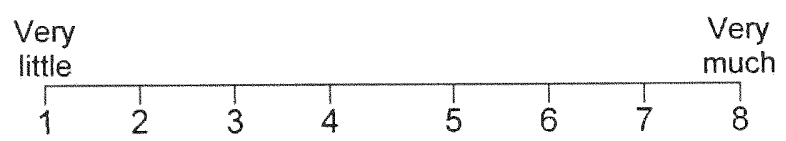
the scale)

12 My knowledge of Occupational Therapy after I begin work within the health care field will be on the scale 1-8:

(Circle the appropriate number on

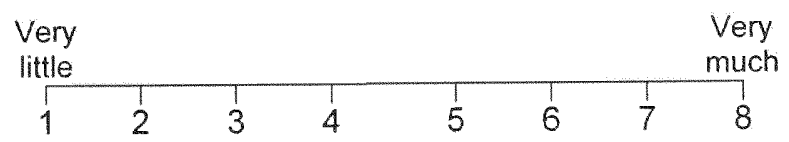
the scale) 
13 At work my professional connection with Occupational Therapy will be on the scale 1-8:

(Circle the appropriate number on the scale)

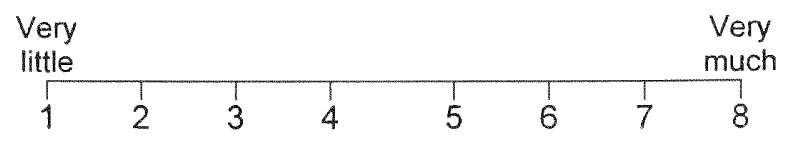

14 The fact sheet changed my ideas about Occupational Therapy on the scale 1-8:

(Circle the appropriate number on the scale)

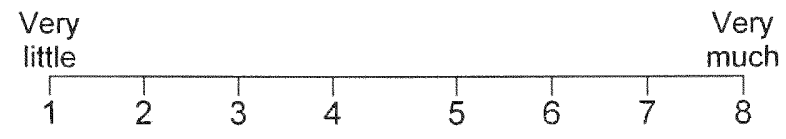

15 There were facts on the fact sheet which I did not know before

(Circle the appropriate number on the scale)

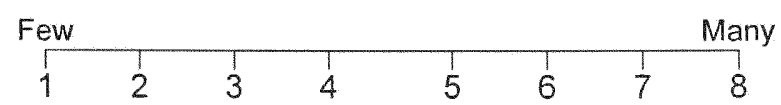

IF YOU HAVE ANY REMARKS OR WANT TO ADD TO THE QUESTIONS FILL OUT THE FOLLOWING TABLE.

\begin{tabular}{|l|l|}
\hline Question no. & Remarks \\
\hline & \\
\hline & \\
\hline & \\
\hline & \\
\hline & \\
\hline & \\
\hline & \\
\hline
\end{tabular}

Thank you very much for your participation. 
Form A

\section{Iðjupjálfun: Viơhorf - pekking - Samvinna}

Tilgangur pessarar könnunar er aơ rannsaka viơhorf til iðjupjálfunar og pekkingu á iơjupjálfun. Einnig er spurt um samvinnu milli iojupjálfa og annarra heilbrigðisstétta.

Könnunin er gerő hjá nemendum i fjórum heilbrigðisgreinum innan Háskóla İslands.

Vinsamlega svaraðu spurningunum eftir bestu getu. Ef pú ert i vafa um einhver atriði spyrðu pann sem leggur könnunina fyrir pig. Ef pú hefur athugasemdir við spurningarnar eða vilt bæta einhverju viõ pæer pá gefst rými til pess á aftasta blađinu.

Svörin eru trúnaðarmál og munu ekki hafa áhrif á einkunnir pinar.

Hluti A - Bakgrunnur pinn og kynni pin af iðjupjálfun

4 Hvort ert pú karlmaður eđa kona?

口, Karlmaỗur

$\square$ Kona

5 Hvađa nám stundar pú?

$\square$ Félagsráðgjöf

$\square_{2}$ Hjúkrunarfræði

$\square_{3}$ Læknisfrædi

$\square_{4}$ Sjúkrapjálfun

6 Hvar heyroir pủ fyrst um iðjupjálfun? (merkið eingöngu við einn valkost)

$\square$, Ég hef aldrei heyrt um iojupjálfun

$\Rightarrow$ pú parft ekki ad ljúka vio spurningalistann. Takk fyrir pátttökuna..

$\square_{2}$ í skólanum

$\square_{3}$ I fjölmiōlum

$\square_{4}$ I samrædum

$\square_{5}$ Á almennum vinnumarkaői

$\square_{6}$ i verknámi

$\square_{7}$ Hjá vini eđa fjölskyldu

$\square_{8}$ pegar ég var í međfero hjá iőjupjálfa

$\square$, pegar fjölskyldumeđ̌limur eđa vinur var i međferð hjá iðjupjálfa

$\square_{10}$ Annaठ: $\Rightarrow$ Hvað? 


\begin{tabular}{|c|c|c|c|c|}
\hline & & Já & Nei & Veit ekki \\
\hline \multirow[t]{2}{*}{4} & $\begin{array}{l}\text { Hafa verio gefnar upplýsingar um iojojupjálfun } \\
\text { í pínu námi? }\end{array}$ & $\square_{1}$ & $\square_{2}$ & $\square_{3}$ \\
\hline & Ef nei, svariơ pá næest spurningu 6 & & & \\
\hline 5 & $\begin{array}{l}\text { Telur pú ad pær upplýsingar hafi verið } \\
\text { næegar? }\end{array}$ & $\square_{1}$ & $\square_{2}$ & $\square_{3}$ \\
\hline \multirow[t]{2}{*}{6} & $\begin{array}{l}\text { Voru heimsóknir á ỉojupjálfunardeildir liđir î } \\
\text { pínu námi? }\end{array}$ & $\square_{1}$ & $\square_{2}$ & $\square_{3}$ \\
\hline & Ef nei, svario pá næst spurningu 6 & & & \\
\hline 7 & Uppfylltu pæer heimsóknir væntingar pínar? & $\square_{1}$ & $\square_{2}$ & $\square_{3}$ \\
\hline 8 & Dekkir pú verksviõ iõjupjálfa? & $\square_{1}$ & $\square_{2}$ & $\square_{3}$ \\
\hline 9 & $\begin{array}{l}\text { Skilur pú hlutverk og gagnsemi } \\
\text { iőjupjálfunar? }\end{array}$ & $\square_{1}$ & $\square_{2}$ & $\square_{3}$ \\
\hline 10 & Telur pú iojupjálfun skylda annarri fagstétt? & $\square_{1}$ & $\square_{2}$ & $\square_{3}$ \\
\hline & Ef já: $\Rightarrow$ Hverri? & & & \\
\hline
\end{tabular}

Hluti C - Samvinna

\begin{tabular}{|c|c|c|c|c|c|c|}
\hline & & $\begin{array}{l}\text { Mjög } \\
\text { sammála }\end{array}$ & $\begin{array}{l}\text { Fremur } \\
\text { sammála }\end{array}$ & Hlutlaus & $\begin{array}{l}\text { Fremur } \\
\text { ósammála }\end{array}$ & $\begin{array}{c}\text { Mjög } \\
\text { ósammála }\end{array}$ \\
\hline 11 & $\begin{array}{l}\text { Eg hef naegar upplýsingar } \\
\text { um iōjubjálfun til aó skilja } \\
\text { störf iojubjálfa i } \\
\text { heilbrigoispjónustu. }\end{array}$ & $\square$, & $\square_{2}$ & $\square_{3}$ & $\square_{4}$ & $\square_{5}$ \\
\hline 12 & $\begin{array}{l}\text { Ég á von á pví ad̃ starfa } \\
\text { med iojupjálfa î framtiơinni }\end{array}$ & $\square_{1}$ & $\square_{2}$ & $\square_{3}$ & $\square_{4}$ & $\square_{5}$ \\
\hline 13 & $\begin{array}{l}\text { Ég hef nægar upplýsingar } \\
\text { um idjubjálfun til að starfa } \\
\text { meo iđjubjálfa }\end{array}$ & $\square_{1}$ & $\square_{2}$ & $\square_{3}$ & $\square_{4}$ & $\square_{5}$ \\
\hline
\end{tabular}




\begin{tabular}{|c|c|c|c|c|c|c|}
\hline & & $\begin{array}{c}\text { Mjög } \\
\text { sammála }\end{array}$ & $\begin{array}{l}\text { Fremur } \\
\text { sammála }\end{array}$ & Hlutlaus & $\begin{array}{c}\text { Fremur } \\
\text { ósammála }\end{array}$ & $\begin{array}{c}\text { Mjög } \\
\text { ósammála }\end{array}$ \\
\hline 14 & $\begin{array}{l}\text { Eg vil breyta samstarfi } \\
\text { minnar fagstéttar og } \\
\text { iojubjálfunar }\end{array}$ & $\square_{1}$ & $\square_{2}$ & $\square_{3}$ & $\square_{4}$ & $\square_{5}$ \\
\hline
\end{tabular}

15 Ef pú ert sammála fullyròingunni í spurninu 14, hvernig viltu pá breyta samstarfinu? (Merkið viỏ pá liđi sem eiga vid)

Ég vil að

Ég vil að

a) Fræðsla verði:

$\square$ aukin

$\square_{2}$ minnkuð

Ég vil að

b) Samskipti verði:

$\square$, aukin

$\square_{2}$ minnkuo

Ég vil ao

c) Samvinna verö:

$\square$ aukin

$\square_{2}$ minnkuo

d) Upplýsingar verð::

$\square_{1}$ aukin

$\square_{2}$ minnkuo

e) Annao: $\Rightarrow$ Hvað?

Hluti D - Viðhorf

\begin{tabular}{|c|c|c|c|c|c|c|}
\hline & & $\begin{array}{l}\text { Mjög } \\
\text { sammála }\end{array}$ & $\begin{array}{l}\text { Fremur } \\
\text { sammála }\end{array}$ & Hlutlaus & $\begin{array}{l}\text { Fremur } \\
\text { ósammála }\end{array}$ & $\begin{array}{c}\text { Mjög } \\
\text { ósammála }\end{array}$ \\
\hline 16 & $\begin{array}{l}\text { Mín fagstétt og iojubjálfun } \\
\text { eiga margt sameiginlegt }\end{array}$ & $\square_{1}$ & $\square_{2}$ & $\square_{3}$ & $\square_{4}$ & $\square_{5}$ \\
\hline 17 & $\begin{array}{l}\text { Minni fagstétt og } \\
\text { ¡jupjálfun er æetlad ao } \\
\text { bæta hvora aðra upp }\end{array}$ & $\square_{1}$ & $\square_{2}$ & $\square_{3}$ & $\square_{4}$ & $\square_{5}$ \\
\hline 18 & $\begin{array}{l}\text { Ég tel pörf fyrir iojubjálfun i } \\
\text { heilbrigòisgeiranum }\end{array}$ & $\square_{1}$ & $\square_{2}$ & $\square_{3}$ & $\square_{4}$ & $\square_{5}$ \\
\hline 19 & $\begin{array}{l}\text { Ég tel idjupjálfun vera } \\
\text { sterka fagstétt }\end{array}$ & $\square_{1}$ & $\square_{2}$ & $\square_{3}$ & $\square_{4}$ & $\square_{5}$ \\
\hline 20 & \multicolumn{6}{|c|}{$\begin{array}{l}\text { Raðið eftirfarandi heilbrigòisstéttum eftir bví hvert pú telur vera mikilvaegi peirra. } \\
\text { (Merkið } 1 \text { við pá mikilvægustu, } 2 \text { við pá næst mikilvægustu og svo framvegis, upp i 5) }\end{array}$} \\
\hline \multicolumn{7}{|c|}{ Félagsráđgjöf } \\
\hline \multicolumn{7}{|c|}{ Hjủkrunarfræōi } \\
\hline \multicolumn{7}{|c|}{ ¿đjupjálfun } \\
\hline \multicolumn{7}{|c|}{ __ Læknisfræoi } \\
\hline \multicolumn{7}{|c|}{ — Sjúkrabjálfun } \\
\hline
\end{tabular}


Hluti E - Framtiðin

21 pekking mín á iojupjálfun í dag er á kvaroanum 1-8:

(Gerio hring um videigandi tölu á kvarðanum)

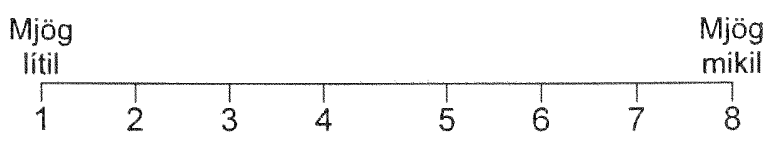

22 pekking min á iðjupjálfun eftir aơ ég hef störf innan

heilbrigdisgeirans

verơur á kvarơanum 1-8:

(Gerio hring um videigandi tölu á kvardanum)

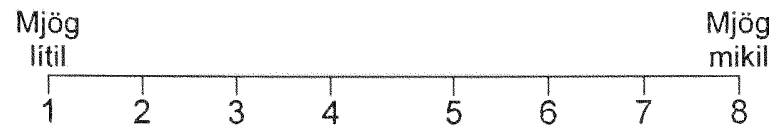

23 Í starfi munu fagleg tengsi mín viò ¡ojupjálfun verỏa á kvarđanum 1-8:

(Gerið hring um videigandi tölu á kvaroanum)

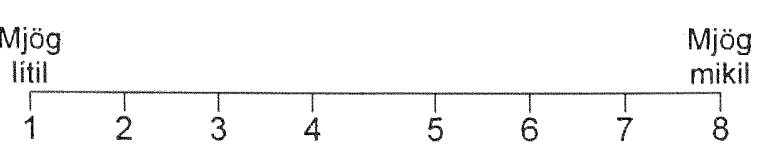

EF DÚ HEFUR ATHUGASEMDIR VIE SPURNINGARNAR FYLLTU DÁ I EFTIRFARANDI TÖFLU.

\begin{tabular}{|l|l|}
\hline Spurning $\mathrm{nr}$. & Athugasemdir \\
\hline & \\
\hline & \\
\hline & \\
\hline & \\
\hline & \\
\hline & \\
\hline & \\
\hline
\end{tabular}

Kærar pakkir fyrir pátttökuna. 
Appendix F - Fact-sheet, in Icelandic

\section{Vissir pú;}

$\checkmark \quad$ aõ aơ á Islandi eru 84 starfandi iojupjálfar i hlutastarfi eða i fullu starfi?

$\checkmark$ að iðjupjálfun varđ til i fyrri heimstyrjöldinni en hefur einungis veriơ heilbrigððisstétt hér á landi i tuttugu ár?

$\checkmark \quad$ aò á Islandi er einn iojjupjálfi á hverja 4500 íbủa landsins, sem er meira en pekkist í öðrum evrópulöndum?

$\checkmark \quad$ ad allir starfandi iðjupjálfar á Íslandi hafa sótt menntun sina til annarra landa? Par mả nefna Danmörku, Noreg, Svipjóđ, Bandarikin, Frakkland, Holland og Åstraliu.

$\checkmark$ ađ um haustið 1997 var stofnuð iðjupjálfanámsbraut við Háskólann á Akureyri?

$\checkmark \quad$ að̃ lengd iojupjálfanáms eru fjögur ár og nemendur fá B.S (Bachelor of Science) í iðjupjálfun?

$\checkmark \quad$ að til eru alheimssamtök iðjupjálfa og aơ Iojjupjálfafélag Íslands er meơlimur i peim?

$\checkmark$ að iðjupjálfun er ein af peim starfstéttum sem eru i hvað örustum vexti i heiminum?

$\checkmark \quad$ að iðjupjálfar vinna á sjúkrahúsum, endurhæfingarstofnunum, skólum, hjúkrunarheimilum, svæơisskrifstofum fatlađra, hjálpartækjamiơstöðvum og sinna einkaráđgjöf?

$\checkmark$ að iðjupjálfar að̌stoða einstaklinga sem eru andlega, líkamlega, proskalega og/eða tilfinningalega fatlaðir?

$\checkmark$ að iojupjálfar ađ̌stoða einstaklinginn við að hæfa, endurhæfa eða viơhalda daglegum athöfnum, námi og/eða vinnu?

$\checkmark \quad$ að̃ iðjupjálfar aðstoða einstaklinginn við að bæta líkamlega færni og að̆lögunarhæfni?

$\checkmark \quad$ að̃ iðjupjálfar aðstoða einstaklinginn við að bæta upp varanlegt tap á virkni?

$\checkmark$ að markmið iðjupjálfunar er að aðstoða einstaklinginn við að viðhalda sjálfstæðum, skapandi og fullnægjandi lifstil?

$\checkmark \quad$ að̃ iðja telst vera athafnir daglegs lifs, vinna og tómstundir?

$\checkmark$ að iðjupjálfar útvega likamlega fötluðum einstaklingum hjálpartæki? Til dæmis hjólastóla, spelkur og önnur hjälpartæki til að̌stoðar i daglegu lifi.

$\checkmark \quad$ að iðjupjálfar hanna og útbúa sérstök hjálpartæki til nota heimafyrir eđa î vinnu?

$\checkmark \quad$ að iðjupjálfar aðstoða einstaklinginn við̃ að laga sig að vinnustað eftir breytingar vegna fötlunar? beir aðstoða við atvinnuleit, skipuleggja vinnuferli, sinna verkpjálfun og meta framfarir einstaklinga.

$\checkmark \quad$ að til að fá meiri upplýsingar um iðjupjálfun getur pú haft samband við iðjupjálfafélag Islands co/Hope Knutsson, Aesufelli 4, tel. 5573734 ? 


\section{Form B}

\section{Iðjupjálfun: Viơhorf - pekking - Samvinna}

Petta er siðari hluti könnunarinnar um viðhorf til iðjupjảlfunar og pekkingu á iojupjálfun.

Könnunin er gero hjá nemendum i fjórum heilbrigđisgreinum innan Háskóla Islands.

Spurningarnar eru að hluta til pæer sömu og á spurningablađ̃ A.

Vinsamlega svaraðu spurningunum eftir bestu getu. Ef pú ert i vafa um einhver atriði spyrðu pann sem leggur könnunina fyrir pig. Ef pú hefur athugasemdir við spurningarnar eða vilt bæta einhverju vio pær pá gefst rými til pess á aftasta blađinu.

Svörin eru trúnađarmál og munu ekki hafa áhrif á einkunnir pínar.

Hluti C - Samvinna

\begin{tabular}{|c|c|c|c|c|c|c|}
\hline & & $\begin{array}{c}\text { Mjög } \\
\text { sammála }\end{array}$ & $\begin{array}{c}\text { Fremur } \\
\text { sammála }\end{array}$ & Hlutlaus & $\begin{array}{c}\text { Fremur } \\
\text { ósammála }\end{array}$ & $\begin{array}{c}\text { Mjög } \\
\text { ósammála }\end{array}$ \\
\hline 1 & 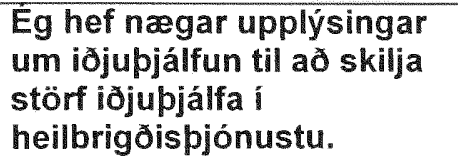 & $\square_{1}$ & $\square_{2}$ & $\square_{3}$ & $\square_{4}$ & $\square_{5}$ \\
\hline 2 & $\begin{array}{l}\text { Ég á von á pví ađ starfa } \\
\text { med idjupjálfa í framtioinni }\end{array}$ & $\square_{1}$ & $\square_{2}$ & $\square_{3}$ & $\square_{4}$ & $\square_{5}$ \\
\hline 3 & $\begin{array}{l}\text { Ég hef nagar upplýsingar } \\
\text { um iojupjálfun til aơ starfa } \\
\text { meơ iojupjálfa }\end{array}$ & $\square_{1}$ & $\square_{2}$ & $\square_{3}$ & $\square_{4}$ & $\square_{5}$ \\
\hline 4 & $\begin{array}{l}\text { I would like to change the } \\
\text { cooperation between my } \\
\text { profession and } \\
\text { Occupational Therapists }\end{array}$ & $\square_{1}$ & $\square_{2}$ & $\square_{3}$ & $\square_{4}$ & $\square_{5}$ \\
\hline
\end{tabular}

5 Ef pú ert sammála fullyroingunni í spurninu 14, hvernig viltu bá breyta samstarfinu? (Merkið við pá liði sem eiga við)

Ég vil ađ

a) Fræosla verði:

$\square$ aukin

$\square_{2}$ minnkuð

Eg vil aó

b) Samskipti verði:

$\square_{1}$ aukin

$\square$ minnkuð

Ég vil ao

c) Samvinna verði:

$\square_{1}$ aukin

$\square$ minnkuð

Ég vil ao

d) Upplýsingar verði:

$\square$, aukin

$\square_{2}$ minnkuð

e) Annad: $\Rightarrow$ Hvað? 


\begin{tabular}{|c|c|c|c|c|c|c|}
\hline & & $\begin{array}{c}\text { Mjög } \\
\text { sammála }\end{array}$ & $\begin{array}{l}\text { Fremur } \\
\text { sammála }\end{array}$ & Hlutlaus & $\begin{array}{l}\text { Fremur } \\
\text { ósammála }\end{array}$ & $\begin{array}{c}\text { Mjög } \\
\text { osammála }\end{array}$ \\
\hline 6 & $\begin{array}{l}\text { Mín fagstétt og iojubjálfun } \\
\text { eiga margt sameiginlegt }\end{array}$ & $\square_{1}$ & $\square_{2}$ & $\square_{3}$ & $\square_{4}$ & $\square_{5}$ \\
\hline 7 & $\begin{array}{l}\text { Minni fagstétt og } \\
\text { iojupjálfun er atlao að } \\
\text { bata hvora aorra upp }\end{array}$ & $\square_{1}$ & $\square_{2}$ & $\square_{3}$ & $\square_{4}$ & $\square_{5}$ \\
\hline 8 & $\begin{array}{l}\text { Ég tel po̊rf fyrir iðjubjálfun í } \\
\text { heilbrigơisgeiranum }\end{array}$ & $\square_{1}$ & $\square_{2}$ & $\square_{3}$ & $\square_{4}$ & $\square_{5}$ \\
\hline 9 & $\begin{array}{l}\text { Ég tel iojubjálfun vera } \\
\text { sterka fagstétt }\end{array}$ & $\square_{1}$ & $\square_{2}$ & $\square_{3}$ & $\square_{4}$ & $\square_{5}$ \\
\hline
\end{tabular}

10 Raðið eftirfarandi heilbrigð̄isstéttum eftir pví hvert pú telur vera mikilvægi peirra. (Merkið 1 við pá mikilvægustu, 2 við pá næst mikilvægustu og svo framvegis, upp i5)

__ Félagsráŏgjöf

___ Húkrunarfræōi

__ Iojupjálfun

__ Læknisfræði

__ Sjúkrapjálfun

Hluti E - Framtioin

11 bekking min á iojupjálfun í dag er á kvarðanum 1-8:

(Gerid hring um viđeigandi tölu á kvarđanum)

12 pekking mín á iojupjălfun eftir aơ ég hef störf innan heilbrigoisgeirans verour á kvarðanum 1-8:

(Gerid hring um viđeigandi tôlu á

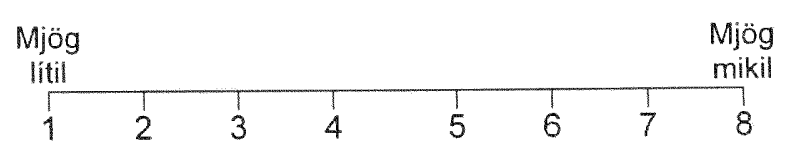
kvardanum)

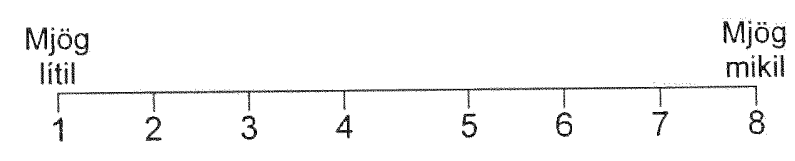


13 Î starfi munu fagleg tengsl mín vio ¡ojupjálfun verơa á kvaroanum 1-8:

(Geriơ hring um viðeigandi tölu á kvardanum)

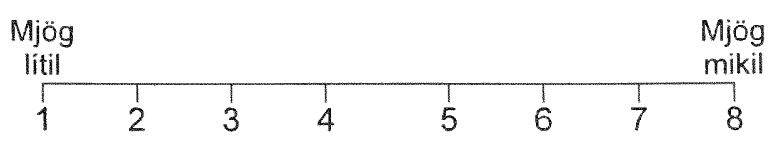

14 Staðreyndablaðio breytti

hugmyndum mínum um iojupjálfun á kvarôanum 1-8:

(Gerið hring um viđeigandi tölu á kvarđanum)

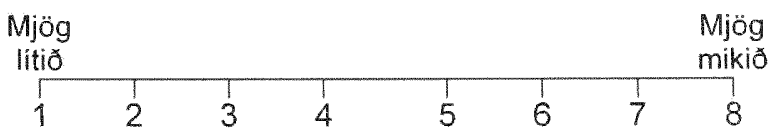

15 Á staơreyndablað̃inu komu fram atriōi um iojupjálfun sem ég vissi ekki ádur; á kvarðanum 1-8:

(Gerið hring um viđeigandi tölu á kvardanum)

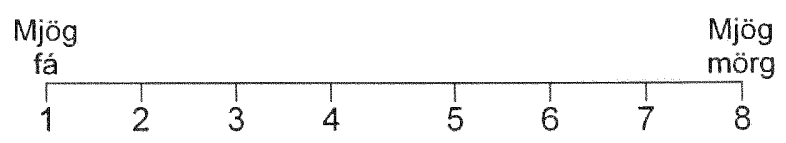

EF DÚ HEFUR ATHUGASEMDIR VIE SPURNINGARNAR FYLLTU DÁ I EFTIRFARANDI TÖFLU.

\begin{tabular}{|l|l|}
\hline Spurning $\mathrm{nr}$. & Athugasemdir \\
\hline & \\
\hline & \\
\hline & \\
\hline & \\
\hline & \\
\hline & \\
\hline & \\
\hline
\end{tabular}

Kærar pakkir fyrir pátttökuna. 